\title{
Systematic review of the epidemiological evidence comparing lung cancer risk in smokers of mentholated and unmentholated cigarettes
}

Peter $N$ Lee

\begin{abstract}
Background: US mentholated cigarette sales have increased considerably over 50 years. Preference for mentholated cigarettes is markedly higher in Black people. While menthol itself is not genotoxic or carcinogenic, its acute respiratory effects might affect inhalation of cigarette smoke. This possibility seems consistent with the higher lung cancer risk in Black men, despite Black people smoking less and starting smoking later than White people. Despite experimental data suggesting similar carcinogenicity of mentholated and non-mentholated cigarettes, the lack of convincing evidence that mentholation increases puffing, inhalation or smoke uptake, and the similarity of lung cancer rates in Black and White females, a review of cigarette mentholation and lung cancer is timely given current regulatory interest in the topic.
\end{abstract}

Methods: Epidemiological studies comparing lung cancer risk in mentholated and non-mentholated cigarette smokers were identified from MedLine and other sources. Study details were extracted and strengths and weaknesses assessed. Relative risk estimates were extracted, or derived, for ever mentholated use and for long-term use, overall and by gender, race, and current/ever smoking, and meta-analyses conducted.

Results: Eight generally good quality studies were identified, with valid cases and controls, and appropriate adjustment for age, gender, race and smoking. The studies afforded good power to detect possible effects. However, only one study presented results by histological type, none adjusted for occupation or diet, and some provided no results by length of mentholated cigarette use.

The data do not suggest any effect of mentholation on lung cancer risk. Adjusted relative risk estimates for ever use vary from 0.81 to 1.12 , giving a combined estimate of 0.93 (95\% confidence interval 0.84-1.02, $\mathrm{n}=8$ ), with no increase in males $(1.01,0.84-1.22, \mathrm{n}=5)$, females $(0.80,0.67-0.95, \mathrm{n}=5)$, White people $(0.87,0.75-1.03, \mathrm{n}=4)$ or Black people $(0.90,0.73-1.10, n=4)$. Estimates for current and ever smokers are similar. The combined estimate for long-term use $(0.95,0.80-1.13, \mathrm{n}=4)$ again suggests no effect of mentholation.

Conclusion: Higher lung cancer rates in Black males cannot be due to their greater preference for mentholated cigarettes. While some study weaknesses exist, the epidemiological evidence is consistent with mentholation having no effect on the lung carcinogenicity of cigarettes.

\section{Background}

According to Giovino et al. [1], who summarized evidence from over 50 countries, the market share of mentholated cigarettes is relatively high in the Philippines (60\%), Cameroon (35-40\%), Hong Kong (26\%), the United States (26\%) and Singapore (22\%), though it is less than $5 \%$ in half the countries considered. They

Correspondence: PeterLee@pnlee.co.uk

P.N. Lee Statistics and Computing Ltd, Surrey, UK reported that, in the United States, Newport brands accounted for $29.7 \%$ of all menthol sales, with Kool (10.8\%), Marlboro menthol (10.5\%) and Salem (10.3\%) about equally distributed. According to Hebert and Kabat [2], mentholated cigarettes were introduced in the 1930s, but did not exceed $3 \%$ of the total US market until 1949, when a slow but steady rise in market share began. The market share was $16 \%$ in 1963, rose to a peak of $29 \%$ in 1979, and then declined somewhat, to $25 \%$, in 1994-1998. The same authors [3] noted that 
about one third of the total production of menthol worldwide is used in the tobacco industry.

There has been increasing regulatory interest in the possible direct or indirect contribution of cigarette additives generally to the occurrence of those diseases resulting from cigarette smoking. This interest not only concerns whether added ingredients may alter the inherent disease risks of smoking, but also includes consideration of whether ingredients may render cigarettes more palatable, so as to increase initiation of smoking or decrease the ability of smokers to quit. The Family Smoking Prevention and Tobacco Control Act, signed into law in the U.S.A. in mid-2009, included a specific provision to ban characterizing flavouring ingredients other than menthol from use in cigarettes. A further review of the exemption of menthol is ongoing at the time of writing, with an advisory report and opinion to be provided to the U.S. Food and Drug Administration by the Tobacco Products Scientific Advisory Committee (TPSAC) in 2011 (http://www.fda.gov/AdvisoryCommittees/CommitteesMeetingMaterials/TobaccoProductsScientificAdvisoryCommittee/default.htm). Similar questions on whether added ingredients may increase the risks, attractiveness or addictiveness of tobacco products have also been posed by the European Commission to the EU Scientific Committee on Emerging and Newly-Identified Health Risks (SCENIHR) (http://ec. europa.eu/health/scientific_committees/consultations/ public_consultations/scenihr_cons_12_en.htm), and the process of public consultation on the SCENIHR preconsultation opinion on added ingredients is presently ongoing.

The principal objective of this paper is to carry out a systematic review, conducted according to the PRISMA guidelines [4] of the epidemiological evidence comparing the risk of lung cancer in smokers of mentholated and non-mentholated cigarettes. As background to this assessment it is helpful to start by summarizing other relevant evidence related to menthol itself and to mentholated cigarettes.

\section{Menthol}

Menthol $\left(\mathrm{C}_{10} \mathrm{H}_{19} \mathrm{OH}\right)$ is a monocyclic terpene alcohol occurring as four pairs of optical isomers. (-) - Menthol, often referred to as 1-menthol, is the isomer most widely seen in nature, and is the one assumed by the name menthol. It occurs naturally in over 100 essential oils [5], in high concentrations in peppermint oil (from Mentha piperita) and cornmint, or Japanese, mint oil (from Mentha arvensis), being readily extracted from the plant by steam distillation [6]. It has a characteristic peppermint odour and gives a cooling sensation when applied to skin and mucosal surfaces [6]. It has been widely used for many years, and there seems no reason for concern that it is carcinogenic or genotoxic $[7,8]$. A recent review [9] notes that menthol is currently approved by the US FDA for use in over-the-counter lozenges, topical preparations and vapour inhalation products based on its antipuritic and antitussive properties, and is widely used as a food flavouring, for which it is declared "Generally Recognized as Safe" (GRAS).

Eccles [6] has reviewed the evidence relating to possible effects of menthol, including nasal decongestant activity, inhibition of respiratory reflexes, antitussive efficacy, effects on mucus production and mucociliary clearance, improvement of pulmonary function and enhancement of sensations in the oral cavity. Although the evidence is not always very clear, it suggests that menthol has an acute effect on the mouth, nose and respiratory tract and certainly leaves open the possibility that menthol in cigarettes might affect puff volume, depth of inhalation and other aspects of how a cigarette is smoked. More recently, Garten and Falkner [10] speculated that menthol might induce unconscious breath holding, so allowing for greater transfer of inhaled tobacco smoke constituents into the pulmonary blood, and hence leading to an increased dependence on nicotine and risk of tobacco attributable disease.

\section{Mentholated cigarettes}

\section{Carcinogenicity, genotoxicity and pharmacological effects}

While combustion of menthol under anaerobic pyrolysis conditions can produce compounds such as 3,4-benzpyrene which are known carcinogens [11-13], menthol pyrolysis in cigarettes does not give rise to any measurable amounts of 3,4-benzpyrene [9,14-19], and there are no notable differences in benzpyrene between major US mentholated and non-mentholated cigarette brands [20].

Two studies compared mouse skin activity of condensates prepared from mentholated and non-mentholated cigarettes, but found no significant difference in either tumourigenic activity [21] or tumour promoting potential [22]. Gaworski et al. [5,23] reported results from two 13-week inhalation studies where rats were exposed to the smoke of cigarettes with or without added menthol, or to filtered air. In the second experiment [23], the test cigarette differed from the reference cigarette in having various other flavour ingredients added as well as menthol. In both studies, dose-related histopathological changes, mainly of respiratory tract epithelia, were found in rats exposed to mainstream smoke. However, the changes were similar in cigarettes with and without menthol, not neoplastic, and diminished significantly after a 6 -week recovery period. A later 90 day study [24] also found no meaningful differences in smoke-related changes between the mentholated and non-mentholated cigarettes. Although these results provide no concern regarding possible carcinogenic effects 
resulting from cigarette mentholation, it should be noted that results of long term $(2 \mathrm{yr}+)$ inhalation studies have never been reported.

Heck [9] recently reviewed evidence comparing the in vitro cytotoxicity and genetic toxicity of smoke condensates and gas-phase material from mentholated and non-mentholated cigarettes, finding no meaningful differences.

\section{Effects on smoking characteristics}

Many studies [25-44] have compared mentholated and non-mentholated cigarette smokers on one or more of the most commonly studied smoking indices: number of puffs, puff volume, carbon monoxide (CO) and cotinine. Nearly all the studies cited took into account possible racial differences. Of seven studies investigating number of puffs, four [25-28] found no significant effect of mentholation, and three [29-31] reporting significantly fewer puffs when smoking mentholated cigarettes. Of six studies on puff volume, two studies [26,27] found no effect, three [29-31] a significant decrease when smoking mentholated cigarettes, and one [32] a significant increase. While three studies $[26,33,34]$ found an increase in CO level associated with mentholation (and one [30] claimed an increase not apparent from the analyses presented), many studies [25,28,29,31,35-39] found no effect of mentholation, and one [27] reported reduced $\mathrm{CO}$ in mentholated cigarette smokers. Three studies [32-34] reported a significant increase in cotinine level associated with mentholation, but nine studies [27,37-44] did not, one of these[39] being based on more subjects $(3,341)$ than all the other studies combined. Most of this evidence was considered in a review in 2007 [45] which, taking also into account other evidence (e.g. on heart rate, blood pressure, total particulate matter, and serum thiocyanate) concluded that "Taken as a whole, the data provide little consistent support for the idea that mentholation may affect how a cigarette is smoked so as to increase uptake of toxic smoke constituents". A more recent review reached similar conclusions [9].

Five studies have compared age of starting to smoke in mentholated and non-mentholated cigarette smokers. No significant differences were seen in the largest study [46], which involved over 10,000 subjects and adjusted for race, in two studies in Black people $[47,48]$, or in two other studies $[49,50]$ which did not adjust for race.

Two very large studies [51,52], each of over 10,000 subjects, reported that, in both Black and White people, mentholated cigarette smokers smoked significantly fewer cigarettes per day than did non-mentholated cigarette smokers. Reduced cigarette consumption has also been reported in four other studies [39,50,53,54], though two [53,54] did not adjust for race and one [39] reported that the reduction was only evident in Black people, with an increase in White people. However, no significant difference was seen in another study of over 10,000 subjects [46] which did adjust for race, or in other studies, three conducted in Black people $[47,48,55]$, one mainly in White people [56], and two $[49,57]$ which did not take race into account.

Sixteen studies have reported results on quitting, race being accounted for in all but one [53]. The two largest $[46,52]$ found no difference by mentholation. No significant differences were also seen in eight other studies $[47,49,54,56,58-61]$. However, reduced quitting was reported in six studies [48,50,53,62-64], though in two of these $[62,63]$, both trials of smoking cessation, the lower quit rate in mentholated cigarette smokers was only seen in the first month or so, longer follow-up of the subjects finding no difference in quit rate. In one study [64], the reduced rate of quitting was only evident in Black and Hispanic people combined, a significantly increased rate of quitting being seen in White people.

The evidence summarized above does not suggest that mentholation of cigarettes is associated with an earlier (or later) age of starting smoking or any increase in cigarette consumption per smoker. Any effect on quitting, if it exists, seems probably quite small.

\section{Differences between Black and White people in the US Relative use of mentholated cigarettes}

Among United States smokers, preference for mentholated cigarettes is much greater in Black than White people. Data from the 2008 National Survey on Drug Use and Health (NSDUH) presented in Table 1 show

Table 1 Relative use of mentholated cigarettes in US Black and White people in 2008 by gender and age ${ }^{a}$

\begin{tabular}{|c|c|c|c|}
\hline \multirow[b]{2}{*}{ Gender } & \multirow[b]{2}{*}{ Age } & \multicolumn{2}{|c|}{$\begin{array}{l}\% \text { of current smokers using mentholated } \\
\text { cigarettes }^{b}\end{array}$} \\
\hline & & White people & Black people \\
\hline \multirow[t]{6}{*}{ Male } & $12-17$ & 45.1 & 79.1 \\
\hline & $18-25$ & 29.5 & 86.5 \\
\hline & $26-34$ & 22.7 & 89.6 \\
\hline & $35-49$ & 14.9 & 87.9 \\
\hline & $50+$ & 20.2 & 70.4 \\
\hline & All ages & 21.8 & 83.5 \\
\hline \multirow[t]{6}{*}{ Female } & $12-17$ & 46.9 & 51.8 \\
\hline & $18-25$ & 36.0 & 88.7 \\
\hline & $26-34$ & 24.1 & 94.0 \\
\hline & $35-49$ & 28.0 & 95.1 \\
\hline & $50+$ & 28.6 & 89.4 \\
\hline & All ages & 29.6 & 90.9 \\
\hline
\end{tabular}

a Derived from the NSDUH (http://www.icpsr.umich.edu/cgi-bin/SDA/ SAMHDA).

${ }^{\mathrm{b}}$ Current smokers were asked whether they had smoked mentholated or regular cigarettes most in the past 30 days. 
the difference is clearly seen in both sexes and in all age groups (except for 12-17 year-old females). It can also be seen in earlier NSDUH surveys (see [45]). Despite this marked difference, the much higher proportion of White people implies that many more White than Black people smoke mentholated cigarettes. The tendency for Black people to prefer mentholated cigarettes has long been evident. For example, in a national study in 1986 cited by the US Surgeon-General [65], 75.5\% of Black and $23.1 \%$ of White smokers used mentholated cigarettes.

\section{Relative lung cancer rates in Black and White people in the} US

United States data for 2001 to 2005 combined [66] show that age-adjusted incidence rates were $36 \%$ higher in Black men than in White men, and mortality rates $31 \%$ higher. In females, however, incidence rates were $0.5 \%$ lower and mortality rates $5 \%$ lower. Table 2 shows US lung cancer mortality rates by race, gender, year (2000, 2005), and age. In both sexes, the ratio of rates in Black people compared to White people tends to decline with age, with the clearest excesses seen in younger males (especially in 2000), lesser excesses seen in older males and younger females, and no excess seen in older

Table 2 Relative lung cancer mortality rates in US White and Black people by gender, year and age ${ }^{a}$

\begin{tabular}{|c|c|c|c|c|c|c|c|}
\hline \multirow[b]{2}{*}{ Gender } & \multirow[b]{2}{*}{ Year } & \multirow[b]{2}{*}{ Age } & \multicolumn{2}{|c|}{ White people } & \multicolumn{2}{|c|}{ Black people } & \multirow{2}{*}{$\begin{array}{c}\text { Black/White } \\
\text { Rate }\end{array}$} \\
\hline & & & Deaths & Rate & Deaths & Rate & \\
\hline \multirow[t]{10}{*}{ Male } & 2000 & $35-44$ & 1133 & 6.1 & 361 & 13.3 & 2.19 \\
\hline & & $45-54$ & 5588 & 35.7 & 1383 & 70.7 & 1.98 \\
\hline & & $55-64$ & 15173 & 150.7 & 2436 & 223.4 & 1.48 \\
\hline & & $65-74$ & 27516 & 374.7 & 3340 & 488.7 & 1.30 \\
\hline & & $75-84$ & 23406 & 529.7 & 2118 & 641.3 & 1.21 \\
\hline & 2005 & $35-44$ & 943 & 5.3 & 203 & 7.6 & 1.43 \\
\hline & & $45-54$ & 5803 & 33.2 & 1334 & 56.9 & 1.71 \\
\hline & & $55-64$ & 15510 & 123.4 & 2721 & 199.1 & 1.61 \\
\hline & & $65-74$ & 24627 & 331.7 & 3011 & 408.6 & 1.23 \\
\hline & & $75-84$ & 24598 & 519.7 & 2066 & 564.3 & 1.09 \\
\hline \multirow[t]{10}{*}{ Female } & 2000 & $35-44$ & 957 & 5.2 & 222 & 7.3 & 1.40 \\
\hline & & $45-54$ & 3941 & 24.8 & 746 & 32.8 & 1.33 \\
\hline & & $55-64$ & 10304 & 96.0 & 1289 & 95.3 & 0.99 \\
\hline & & $65-74$ & 18663 & 213.1 & 1885 & 194.1 & 0.91 \\
\hline & & $75-84$ & 18299 & 272.5 & 1315 & 224.2 & 0.82 \\
\hline & 2005 & $35-44$ & 907 & 5.2 & 184 & 6.1 & 1.17 \\
\hline & & $45-54$ & 4230 & 24.0 & 914 & 33.5 & 1.40 \\
\hline & & $55-64$ & 10947 & 82.6 & 1489 & 87.8 & 1.06 \\
\hline & & $65-74$ & 17883 & 207.1 & 1899 & 184.5 & 0.89 \\
\hline & & $75-84$ & 19816 & 288.3 & 1632 & 253.2 & 0.88 \\
\hline
\end{tabular}

${ }^{a}$ Derived from the National Center for Health Statistics website (http://wonder. cdc.gov). females. Although it is often suggested (e.g. [17,67-69]) that the greater preference of Black people for mentholated cigarettes might help explain their higher lung cancer rates, the greater preference is similarly evident in both genders, but the excess lung cancer rate is only in males.

\section{Differences in smoking habits between Black and White people in the US}

In the United States, there are other relevant differences in smoking habits between White and Black smokers. Table 3 summarizes findings from the National Health Interview Survey for 2006. These are consistent with other evidence (e.g. $[17,46,65,70-72])$ that Black people have a slightly higher prevalence of smoking, a later age of starting to smoke, a lower daily cigarette consumption per smoker, a lower propensity to quit, and a preference for cigarettes higher in tar and nicotine. According to Novotny et al. [70] the difference in smoking prevalence by race disappears if adjustment is made for occupation, education and other socioeconomic and demographic factors, but the differences in amount smoked per smoker and probability of quitting do not.

The evidence is also consistent that Black smokers have higher cotinine levels than White smokers [44,73-77]. In one large study [73] serum cotinine levels averaged $210.2 \mathrm{ng} / \mathrm{ml}$ in White men, $244.8 \mathrm{ng} / \mathrm{ml}$ in Black men, $176.4 \mathrm{ng} / \mathrm{ml}$ in White females and 251.2 in Black females. After adjusting for age, education, gender, cigarettes/day, nicotine content, years of smoking, inhalation frequency and ETS exposure, the difference was estimated to be $83.3 \mathrm{ng} / \mathrm{ml}$, with the higher level in Black people significant for both mentholated cigarette smokers $(89.0 \mathrm{ng} / \mathrm{ml})$ and non-mentholated cigarette smokers $(51.5 \mathrm{ng} / \mathrm{ml})$.

Of the characteristics considered above, some would predict lower lung cancer rates in Black people (fewer ever smokers, later age of starting, and lesser amount smoked per smoker) and some higher rates (more current smokers, reduced quitting, higher tar level, and higher cotinine levels).

\section{Methods}

\section{Selection of studies}

Studies selected satisfied four conditions: based on research on humans, of cohort or case-control design, any form of lung cancer as the outcome, and risk estimates comparing mentholated and non-mentholated cigarette smokers available or able to be calculated.

Relevant publications were initially sought from a MedLine search conducted in August 2010, on "Lung cancer and (menthol or mentholated cigarettes)" limited to "Humans", from recent reviews relating to mentholated cigarettes $[9,45]$, and from reference lists of relevant publications identified. Subsequently, in February 
Table 3 Differences in cigarette smoking habits between White and Black adults - findings from the National Health Interview Survey for $2006^{a}$

\begin{tabular}{lllll}
\hline & $\begin{array}{l}\text { Males } \\
\text { White people }\end{array}$ & Black people & $\begin{array}{l}\text { Females } \\
\text { White people }\end{array}$ & Black people \\
\hline $\begin{array}{l}\text { Among the whole population } \\
\text { Ever smoked (100 cigarettes) }\end{array}$ & $49.9 \%$ & $42.8 \%$ & $38.2 \%$ & $28.7 \%$ \\
$\begin{array}{l}\text { Current smoker } \\
\text { Among ever smokers }\end{array}$ & $23.7 \%$ & $27.0 \%$ & $18.5 \%$ & $18.9 \%$ \\
$\begin{array}{l}\text { Current smoker } \\
\text { Age of starting to smoke (mean, yrs) }\end{array}$ & $47.5 \%$ & $63.0 \%$ & $48.4 \%$ & $66.0 \%$ \\
Among current smokers & 16.9 & 18.4 & 17.9 & 19.2 \\
Number smoked per day (mean) & 16.1 & 11.4 & 13.9 & 10.0 \\
\hline
\end{tabular}

${ }^{a}$ Derived from http://www.icpsr.umich.edu/cgi-bin/SDA/ICPSR.

${ }^{b}$ Includes current every day and some day smokers.

2011, the MedLine search was repeated, and additional papers sought from further similar searches conducted using Google Scholar, Scopus, Scirus, Science Direct and Academic Search Complete, and also from reference lists of new relevant publications identified.

\section{Data extraction}

From each publication details extracted included:

- study design (prospective cohort, hospital case-control, population case-control)

- study location and timing

- sexes, races and age groups studied

- whether current or ever smokers were studied

- other inclusion criteria

- cases - definition, number studied

- controls (for case-control studies) - definition, matching to cases, number studied

- at risk population (for cohort studies) - definition, number studied

- questions asked relating to mentholation of cigarettes (and brands of cigarettes smoked) and the variables used to quantify exposure

- statistical methods used for analysis

- adjustment variables considered

- availability of results by histological type, and

- main conclusions reached by the authors.

\section{Relative risk estimates}

For simplicity, the term "relative risk" (RR) is used generically in this paper to include various estimators of it, including the odds ratio and the hazard ratio.

Studies varied in the extent to which they reported estimates of RR with a 95\% confidence interval (CI). The reported estimates were supplemented by derived estimates, in an effort to present, as far as possible, estimates by extent of mentholated cigarette use and overall, by gender separately and combined, by race separately and combined, by age groups separately and combined, by histological type of lung cancer separately and combined, in current or ever smokers separately and combined, and also by extent of adjustment for confounding variables. The full set of RR (CI) estimates for each study, reported and derived, are given in the tables which describe the results for each individual study. Details of how the various estimates were derived are given in additional file 1: Methods for deriving RR estimates. Three main techniques were used: Unadjusted estimates were derived from numbers of cases and controls using standard methods [78], independent estimates were combined using fixed-effect meta-analysis [79], and non-independent estimates (relative to a common comparison group) were combined using the method of Hamling et al. [80].

\section{Summary of study characteristics, strengths and weaknesses}

The features of the studies were first described studyby-study and then summarized in a table. For each of a number of features (study type, location, timing, possible overlaps between the studies, number of cases, adequacy of cases, adequacy of controls, reliability of data collected, adjustment for potential confounding variables, and statistical methods used), the propensity for bias was considered, and strengths and weaknesses of the overall evidence of specific studies evaluated. Study quality was also independently assessed, using the ninepoint Newcastle-Ottawa Quality Assessment Scale (NOS) [81], by the author and a colleague (K.J. Coombs), with any discrepancies resolved by discussion.

\section{Meta-analyses}

Fixed-effect and random-effects meta-analyses were conducted, and heterogeneity chisquared statistics estimated, using standard methods [79]. The principal comparison was between smokers who had ever or never used mentholated cigarettes, though as this was 
not available in some studies RRs for similar comparisons (e.g. usual brand mentholated cigarettes or not; current brand mentholated or not) were also included in the meta-analysis. A secondary comparison used the same comparison group (never or non-current mentholated cigarettes), but assessed risk relating to long-term use of mentholated cigarettes, using the maximum extent of exposure available for the study (e.g. 20+ years use or $32+$ pack-years use). The main analyses used combined estimates for the whole population studied, but subgroup analyses give results by gender, race, smoking status, study quality, study size (number of cases in mentholated cigarette smokers), study design, and publication date. Sensitivity analyses excluded the smaller of these studies, where there was a possible overlap in cases between studies. For the main analysis, publication bias was investigated by Egger's test [82] and by a funnel plot, in which the logarithm of the RR is plotted against its (inverse-variance) weight.

\section{Checking}

Dr. J.S. Fry independently checked the extraction of data from the source publications, the derivation of additional relative risk estimates and the conduct of the meta-analyses. Any differences found were resolved in discussion with the author.

\section{Results}

\section{Studies identified}

Eight epidemiological studies were identified that provided evidence on the relative risk of lung cancer associated with cigarette mentholation. Six $[51,53,56,68,69,83]$ were identified from the MedLine search conducted in August 2010, with a further two $[84,85]$ referred to in the review by Heck [9]. No further relevant studies were identified from other sources, including the later searches conducted in February 2011. Fuller details of the sequence of searches made, and the number of papers identified, rejected and accepted at the various stages are shown in Figure 1.

Apart from a case-control study in Germany, reported only as an abstract [84], all the studies were conducted in the USA. Two of these are of prospective cohort design $[51,56]$, the remaining five being case-control studies $[53,68,69,83,85]$. In the following sections, the eight studies are described in chronological order of publication and their relevant results summarized.

\section{Study descriptions and results}

\section{American Health Foundation multicentre case-control study}

The first paper [68] to report results relating use of mentholated cigarettes to risk of lung cancer, published in 1991, was based on data from a long-term multicentre hospital case-control study. This involved patients with tobacco-related cancers and controls - hospitalized patients with conditions thought not associated with smoking - matched to the cases on age, gender, race, hospital and date of interview. The analyses were restricted to current smokers of cigarettes (defined as subjects who had smoked in the year preceding diagnosis) who were interviewed between 1985 and 1990 in one of eight hospitals in four US cities. They included 588 male and 456 female histologically confirmed lung cancer cases and 914 male and 410 female controls.

All patients were interviewed in hospital using a standard questionnaire. This contained questions on the type of tobacco products used throughout life, brands of cigarettes smoked, cigarettes per day, use of filter and non-filter cigarettes, use of mentholated cigarettes, years of smoking each brand and age at initiation. Information on mentholation was obtained for each brand of cigarette reported.

Table 4 summarizes the results of unconditional logistic regression analyses used to estimate the risk of lung cancer associated with smoking mentholated cigarettes for 1-14 years or $15+$ years relative to never having smoked mentholated cigarettes, with adjustment for age, race, education, cigarettes per day (of the current brand), inhalation, duration of smoking, body mass index and, where appropriate, also gender. Without adjustment for potential confounding variables, use of mentholated cigarettes was associated with a reduced risk of lung cancer, not significantly in males (RR 0.92; CI 0.73-1.17) but significantly in females (RR 0.56; CI 0.42-0.75). With adjustment for the variables noted above, however, no significant association was seen (males 1.06; 0.82-1.37, females 0.78; 0.57-1.08). Nor was any association seen when results (only available for the genders combined, and as adjusted relative risks) were considered by histological type.

The authors concluded that: "Use of mentholated cigarettes was not associated with increased risk of lung cancer or of specific histological types of lung cancer in this study" and noted that "If our results are confirmed by other researchers, the implication would be that use of mentholated cigarettes does not explain Black-White differences in lung cancer incidence or time trends."

\section{Kaiser Permanente prospective study}

The second relevant paper identified [51], published in 1995, was based on data from the Northern California Kaiser Permanente Medical Care Program in Oakland, California. The study involved 5771 males and 5990 females aged 30 to 89 years who underwent a multiphasic health check-up between 1979 and 1985, reported they were then current cigarette smokers who had smoked for at least 20 years, and provided details of the mentholation status of the brand of cigarettes they usually smoked. Follow-up for lung cancer was 


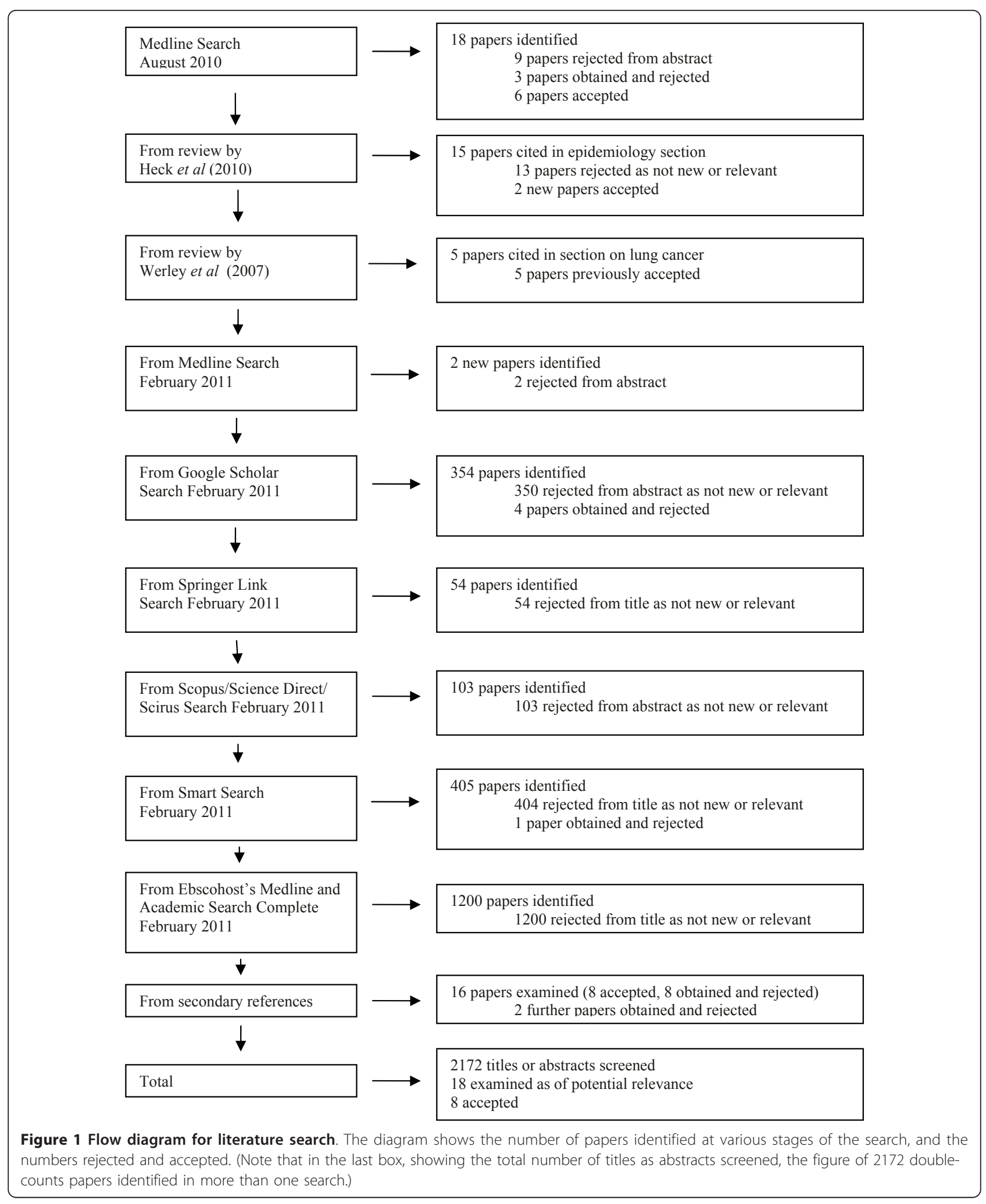


Table 4 Risk of lung cancer by mentholated cigarette use among current smokers - American Health Foundation multicentre case control study [68]

\begin{tabular}{|c|c|c|c|c|c|c|c|}
\hline \multirow[t]{3}{*}{ Histological type of lung cancer } & \multirow[b]{3}{*}{ Gender } & \multirow[b]{2}{*}{ No. of } & & \multicolumn{4}{|c|}{ Years of use of mentholated cigarettes } \\
\hline & & & & Never $^{\mathbf{b}}$ & $1-14$ & $15+$ & Ever ${ }^{c}$ \\
\hline & & Cases & Adjusted $^{a}$ & RR & $\mathrm{RR}(\mathrm{Cl})$ & $\mathrm{RR}(\mathrm{Cl})$ & $\mathrm{RR}(\mathrm{Cl})$ \\
\hline \multirow[t]{6}{*}{ Any } & Male & 588 & $\mathrm{No}^{\mathrm{d}}$ & 1.00 & $0.98(0.72-1.33)$ & $0.87(0.64-1.20)$ & $0.92(0.73-1.17)$ \\
\hline & & & Yes & 1.00 & $1.14(0.82-1.59)$ & $0.98(0.70-1.38)$ & $1.06(0.82-1.37)$ \\
\hline & Female & 456 & $\mathrm{No}^{\mathrm{d}}$ & 1.00 & $0.56(0.38-0.83)$ & $0.55(0.38-0.80)$ & $0.56(0.42-0.75)$ \\
\hline & & & Yes & 1.00 & $0.82(0.52-1.28)$ & $0.76(0.53-1.16)$ & $0.78(0.57-1.08)$ \\
\hline & Combined & 1044 & No ${ }^{d}$ & 1.00 & $0.79(0.62-1.01)$ & $0.72(0.57-0.92)$ & $0.76(0.63-0.91)$ \\
\hline & & & Yes $^{d}$ & 1.00 & $1.02(0.78-1.33)$ & $0.88(0.68-1.14)$ & $0.94(0.77-1.15)$ \\
\hline Squamous cell carcinoma & Combined & 268 & Yes & 1.00 & $1.17(0.78-1.78)$ & $0.92(0.60-1.42)$ & $1.04(0.75-1.44)$ \\
\hline Small cell carcinoma & Combined & 131 & Yes & 1.00 & $0.80(0.43-1.48)$ & $0.86(0.49-1.51)$ & $0.83(0.53-1.30)$ \\
\hline Large cell carcinoma & Combined & 106 & Yes & 1.00 & $1.99(0.73-5.41)$ & $0.84(0.27-2.61)$ & $1.28(0.56-2.91)$ \\
\hline Adenocarcinoma & Combined & 400 & Yes & 1.00 & $0.98(0.68-1.42)$ & $0.95(0.66-1.36)$ & $0.96(0.73-1.28)$ \\
\hline
\end{tabular}

${ }^{a}$ Yes = adjusted for age, race, education, cigarettes per day, inhalation, duration of smoking and body mass index. Combined gender analyses are also adjusted for gender.

${ }^{\mathrm{b}}$ Or less than 1 year mentholated use.

${ }^{c}$ At least 1 year mentholated use.

${ }^{d}$ RRs and Cls estimated as described in additional file 1: Methods for deriving RR estimates.

Table 5 Risk of lung cancer by mentholated cigarette use among current smokers for 20 years or more - Kaiser Permanente prospective study [51]

\begin{tabular}{|c|c|c|c|c|c|c|c|c|}
\hline \multirow[b]{3}{*}{ Gender } & \multirow[b]{3}{*}{ Age } & \multirow[b]{3}{*}{ No. of cases $^{a}$} & \multirow[b]{3}{*}{ Adjusted } & \multicolumn{5}{|c|}{ Duration of mentholated cigarette use (years) } \\
\hline & & & & 0 & $1-9$ & 10-19 & $20+$ & Any \\
\hline & & & & RR & $\mathrm{RR}(\mathrm{Cl})$ & $\mathrm{RR}(\mathrm{Cl})$ & $\mathrm{RR}(\mathrm{Cl})$ & RR (Cl) \\
\hline \multirow[t]{7}{*}{ Male } & $<50$ & $6(3)$ & No & 1.0 & - & - & - & $2.2(0.5-11.1)$ \\
\hline & $50-64$ & $82(24)$ & No & 1.0 & - & - & - & $1.1(0.7-1.8)$ \\
\hline & $65-74$ & $60(22)$ & No & 1.0 & - & - & - & $1.7(1.0-2.9)$ \\
\hline & $75+$ & $20(6)$ & No & 1.0 & - & - & - & $1.7(0.6-4.3)$ \\
\hline & All & $168(55)$ & $\mathrm{Age}^{\mathrm{b}}$ & 1.00 & - & - & - & $1.40(1.01-1.94)$ \\
\hline & All & $160(51)^{c}$ & Age, others ${ }^{d}$ & 1.00 & - & - & - & $1.45(1.03-2.02)$ \\
\hline & All & $158(57)^{e}$ & Age, others ${ }^{d}$ & 1.00 & $1.10(0.65-1.87)$ & $1.32(0.84-2.08)$ & $1.59(0.96-2.63)$ & - \\
\hline \multirow[t]{7}{*}{ Female } & $<50$ & $11(2)$ & No & 1.0 & - & - & - & $0.3(0.1-1.6)$ \\
\hline & $50-64$ & $61(19)$ & No & 1.0 & - & - & - & $0.8(0.5-1.4)$ \\
\hline & $65-74$ & $50(10)$ & No & 1.0 & - & - & - & $0.6(0.3-1.1)$ \\
\hline & $75+$ & $28(7)$ & No & 1.0 & - & - & - & $0.9(0.4-2.1)$ \\
\hline & All & $150(38)$ & $\mathrm{Age}^{\mathrm{b}}$ & 1.00 & - & - & - & $0.71(0.50-1.00)$ \\
\hline & All & $138(34)^{c}$ & Age, others ${ }^{d}$ & 1.00 & - & - & - & $0.75(0.51-1.11)$ \\
\hline & All & $132(42)^{c}$ & Age, others ${ }^{d}$ & 1.00 & $0.72(0.38-1.39)$ & $1.01(0.61-1.69)$ & $0.70(0.40-1.23)$ & - \\
\hline \multirow[t]{7}{*}{ Combined } & $<50$ & $17(5)$ & Gender $^{b}$ & 1.00 & - & - & - & $0.73(0.26-2.04)$ \\
\hline & $50-64$ & $143(43)$ & Gender $^{\mathrm{b}}$ & 1.00 & - & - & - & $0.95(0.67-1.35)$ \\
\hline & $65-74$ & $110(32)$ & Gender $^{\mathrm{b}}$ & 1.00 & - & - & - & $1.12(0.74-1.69)$ \\
\hline & $75+$ & $48(13)$ & Gender $^{\mathrm{b}}$ & 1.00 & - & - & - & $1.17(0.62-2.21)$ \\
\hline & All & $318(93)$ & Gender, age ${ }^{b}$ & 1.00 & - & - & - & $1.02(0.80-1.29)$ \\
\hline & All & $298(85)^{c}$ & Gender, age, others ${ }^{b, d}$ & 1.00 & - & - & - & $1.09(0.85-1.41)$ \\
\hline & All & $290(99)^{c}$ & Gender, age, others ${ }^{b, d}$ & 1.00 & $0.93(0.62-1.40)$ & $1.17(0.84-1.65)$ & $1.10(0.76-1.60)$ & - \\
\hline
\end{tabular}

\footnotetext{
${ }^{a}$ The first number includes non-mentholated cigarette smokers and the bracketed number is for mentholated cigarette smokers only

${ }^{\mathrm{b}} \mathrm{RRs}$ and $\mathrm{Cls}$ derived as described in additional file 1: Methods for deriving RR estimates.

c There were fewer subjects in the analyses adjusted for age and other variables than for those adjusted for age only, presumably because of missing data for the other variables.

${ }^{d}$ The other adjustment factors were race, education, years of smoking and number of cigarettes per day.

e The lesser total cases in this analysis than the previous one is presumably because of missing data on duration of mentholated cigarette use. However, it is unclear why there were more cases who smoked mentholated cigarettes.
} 
determined up to the end of 1991 with 318 incident cases identified, 93 in mentholated cigarette users, 225 in non-mentholated cigarette users, 168 in males and 150 in females.

As shown in Table 5, risks for males were somewhat higher in users than in non-users in every age group and after adjustment for age, the RR could be estimated as 1.40 (CI 1.01-1.94). This marginally statistically significant difference was also seen when adjustment was made for age, race and education as well as years of smoking and cigs/day (using a Cox proportional hazards model), the RR given being 1.45 (1.03-2.02). In males, duration of mentholated cigarette use also showed a significant $(\mathrm{p}=0.02)$ trend with risk of lung cancer. In females, however, risk was somewhat less in users than in non-users with the RR $0.71(0.50-1.00)$ after adjustment for age and 0.75 (0.51-1.11) after additional adjustment for race, education, years of smoking and cigs/day. When data for males and females were combined, with additional adjustment for gender, no significant association was seen.

The authors noted that additional adjustment for aspects of smoking other than years of smoking and cigs/day did not substantially alter the estimate of relative risk for mentholated cigarette use, and concluded that: "This study suggests there is an increased risk of lung cancer associated with mentholated cigarette use in male smokers but not in female smokers."

\section{Los Angeles County case-control study}

Whereas the first two papers limited attention to current cigarette smokers, the third [69] also considered former smokers. This study, conducted in 1991-1994 in Los Angeles County in California and reported in 1999, was of population case-control design. Cases were histologically confirmed and identified within seven months of diagnosis. Controls under age 65 were randomly selected from licensed drivers, whilst those over age 65 were randomly selected from Medicare Beneficiaries. Cases and controls were frequency matched on age, gender and race. Cases and controls had to be resident in Los Angeles County, aged 40-84, able to complete a questionnaire in English, be Caucasian (non-Hispanic) or African American people, and with no previous cancer (other than non-melanoma skin cancer). Subjects were interviewed regarding known and possible risk factors for lung cancer, including smoking history, occupational exposures, ETS exposure and family history of lung cancer. Menthol smoking was classified based on response to the question "On average over your lifetime, out of every 100 cigarettes you smoked, how many were menthol?".

Of 859 cases and 3193 potentially eligible controls, 353 cases and 724 controls were available for interview and provided smoking information including menthol status. The analysis was restricted to the cases (202 males and 135 females) and controls (349 males and 129 females) who had ever smoked (as many as 100 cigarettes in their life). The analyses presented used unconditional logistic regression, with adjustment for age, race, gender, total pack-years and years since quitting smoking. Other potential confounding variables (fruits, vegetables, occupational exposures, family history and ETS) had no appreciable influence on the association with mentholated cigarette smoking and were therefore not included in the regression models.

RRs and CIs were presented by pack-years of mentholated smoking (Table 6), percentage of mentholated cigarettes smoked (Table 7) and type of cigarette smoker (Table 8 ). RRs and CIs are available (or can be derived) which are unadjusted, adjusted for the matching factors gender, age and race, or adjusted for the matching factors as well as for total pack-years and years since quitting smoking. No results are available for current and former smokers separately. Results by pack-years of mentholated smoking are separately available by gender, and by race.

For all subjects, the RRs comparing smokers who have ever and never used mentholated cigarettes are close to 1.0, when adjustment is made for the matching factors and the smoking variables considered. Due to rounding of RRs presented by level for the three aspects of mentholated cigarette smoking, these calculated estimates are not quite the same in the three tables, being 1.00 (CI 0.72-1.40), 1.01 (0.74-1.40) and 1.02 (0.74-1.40) in Tables 6,7 and 8 respectively. The results in Table 6 also show that the ever/never mentholated RR is quite close to 1 for males $(1.00 ; 0.68-1.48)$, females $(0.88$; $0.50-1.57)$, Caucasian people $(1.02 ; 0.66-1.58)$ or African-American people $(0.89,0.53-1.47)$. Nor is there any evidence of any variation in risk by proportion of mentholated cigarettes smoked (Table 7) or by cigarette smoker type (Table 8). After adjustment for the matching and smoking variables the RR was $1.04(0.62-1.75)$ for exclusive mentholated and 1.01 (0.71-1.42) for mixed menthol/regular (non-mentholated), as compared to exclusive regular.

The only apparent suggestion of an effect of mentholated cigarette smoking is for the results by pack-years (Table 6). In interpreting these results, it is important to realise, that the RRs which are unadjusted or are adjusted only for the matching factors may be biased by the greater likelihood of inclusion of current and long term smokers in the higher pack-years categories. When adjustment is also made for total pack-years and years since quitting, this bias should mainly be removed, though there remains the possibility of some residual confounding. After this adjustment there was no evidence of any variation in risk by pack-years of 
Table 6 Risk of lung cancer by pack-years of mentholated cigarette use among ever smokers - Los Angeles County case-control study [69]

\begin{tabular}{|c|c|c|c|c|c|c|c|}
\hline \multirow{3}{*}{ Gender/Race } & \multirow{3}{*}{ No of cases } & & \multicolumn{5}{|c|}{ Pack-years of mentholated smoking } \\
\hline & & & 0 & $1-15$ & $16-31$ & $32+$ & Any $^{\mathrm{a}}$ \\
\hline & & Adjusted & RR & RR (Cl) & RR (Cl) & RR (Cl) & $\mathrm{RR}(\mathrm{Cl})$ \\
\hline \multirow[t]{3}{*}{ Male/Both } & 202 & No & 1.00 & $0.63(0.42-0.95)$ & $1.40(0.69-2.84)$ & $2.60(1.33-5.08)$ & $0.92(0.65-1.31)$ \\
\hline & & Age, race ${ }^{b}$ & 1.00 & $0.62(0.41-0.93)$ & $1.35(0.67-2.73)$ & $2.52(1.29-4.92)$ & $0.90(0.64-1.28)$ \\
\hline & & Age, race and others ${ }^{c}$ & 1.00 & $0.87(0.57-1.37)$ & $1.21(0.56-2.62)$ & $1.48(0.71-3.05)$ & $1.00(0.68-1.48)$ \\
\hline \multirow[t]{3}{*}{ Female/Both } & 135 & No & 1.00 & $0.90(0.52-1.57)$ & $0.83(0.36-1.96)$ & $0.90(0.38-2.15)$ & $0.89(0.55-1.44)$ \\
\hline & & Age, race ${ }^{b}$ & 1.00 & $0.87(0.50-1.52)$ & $0.68(0.29-1.60)$ & $0.72(0.30-1.71)$ & $0.80(0.49-1.29)$ \\
\hline & & Age, race and others ${ }^{c}$ & 1.00 & $1.58(0.77-3.22)$ & $0.51(0.19-1.34)$ & $0.41(0.15-1.11)$ & $0.88(0.50-1.57)$ \\
\hline \multirow[t]{3}{*}{ Both/White people ${ }^{d}$} & 181 & No & 1.00 & $0.64(0.41-1.00)$ & $1.35(0.58-3.11)$ & $1.80(0.87-3.75)$ & $0.86(0.59-1.26)$ \\
\hline & & Age, gender ${ }^{b}$ & 1.00 & $0.68(0.44-1.06)$ & $1.41(0.61-3.25)$ & $1.78(0.86-3.70)$ & $0.90(0.61-1.31)$ \\
\hline & & Age, gender and others ${ }^{c}$ & 1.00 & $1.01(0.61-1.68)$ & $1.01(0.41-2.47)$ & $1.06(0.47-2.36)$ & $1.02(0.66-1.58)$ \\
\hline \multirow[t]{3}{*}{ Both/Black people } & 156 & No & 1.00 & $0.71(0.43-1.16)$ & $0.91(0.44-1.89)$ & $1.56(0.72-3.37)$ & $0.85(0.55-1.32)$ \\
\hline & & Age, gender ${ }^{\mathrm{b}}$ & 1.00 & $0.66(0.40-1.08)$ & $0.77(0.37-1.60)$ & $1.46(0.68-3.16)$ & $0.78(0.51-1.21)$ \\
\hline & & Age, gender and others ${ }^{c}$ & 1.00 & $0.96(0.54-1.70)$ & $0.69(0.30-1.60)$ & $0.90(0.38-2.12)$ & $0.89(0.53-1.47)$ \\
\hline \multirow[t]{3}{*}{ Both/Both } & 337 & No & 1.00 & $0.72(0.52-1.00)$ & $1.20(0.70-2.06)$ & $1.81(1.07-3.07)$ & $0.93(0.70-1.23)$ \\
\hline & & Age, race and gender ${ }^{b}$ & 1.00 & $0.70(0.51-0.97)$ & $1.04(0.61-1.79)$ & $1.64(0.97-2.76)$ & $0.87(0.66-1.15)$ \\
\hline & & Age, race, gender and others ${ }^{c}$ & 1.00 & $1.05(0.72-1.54)$ & $0.92(0.50-1.68)$ & $0.95(0.53-1.70)^{f}$ & $1.00(0.72-1.40)$ \\
\hline
\end{tabular}

${ }^{a}$ RRs and Cls for any use estimated as described in additional file 1: Methods for deriving RR estimates.

${ }^{b}$ The width of the estimated $\mathrm{Cl}$ is taken to be the same as the width of the unadjusted estimates, so may be slightly too narrow.

c The other adjustment factors were total pack-years and years since quitting.

${ }^{d}$ White people are defined as Caucasian.

e Black people are defined as African-American.

${ }^{f}$ Similarly adjusted RRs and Cls are also available for 32-53 pack-years, 0.76 (0.37-1.59) and 54+ pack-years 1.38 (0.56-3.40). For 54+ pack-years these estimates did not vary between current smokers (RR 1.23, 0.36-1.42) and former smokers (RR 1.78, 0.44-7.19).

mentholation for the total population or for Caucasian or African-American people separately. However, there was some evidence that risk increased with pack-years in males (RRs 1.00, 0.87, 1.21 and 1.48 for $0,1-15,16$ 31 and $32+$ pack-years, trend $\mathrm{p}=0.25)$ and that risk decreased with pack-years in females (RRs 1.00, 1.58, 0.51 and 0.41 , trend $\mathrm{p}=0.04$ ).

The authors concluded that "Our results suggest that the lung-cancer risk from smoking mentholated cigarettes resembles the risk from smoking non-mentholated cigarettes. Our data do not support the hypothesis that the increased risk of lung cancer among African Americans is due to the increased prevalence of menthol smoking."

\section{Slone Epidemiology Center study}

The fourth paper [53], reported in 2003, also considered ever smokers. It concerned a case-control study conducted in 1981-2000 in hospitals in four eastern US states. Cases were confirmed by review of pathology reports, with the diagnoses made within 12 months of admission. Controls were admitted for conditions unrelated to smoking. Cases and controls had to be aged 4074 , have smoked cigarettes for at least 20 years and have no history of cancer. 1300 cases and 9383 controls met the initial eligibility criteria, but analysis was restricted to those cases (435 males and 208 females) and controls (2123 males and 1987 females) for whom brand information could be identified for at least $60 \%$ of

Table 7 Risk of lung cancer by percentage of mentholated cigarettes smoked - Los Angeles County case-control study [69]

\begin{tabular}{|c|c|c|c|c|c|c|c|}
\hline \multirow{3}{*}{ Gender/Race } & \multirow{3}{*}{ No of cases } & & \multicolumn{5}{|c|}{ Percentage of mentholated smoking } \\
\hline & & \multirow[b]{2}{*}{ Adjusted } & 0 & 1-19 & $20-74$ & $75-100$ & Any $^{a}$ \\
\hline & & & RR & $\mathrm{RR}(\mathrm{Cl})$ & RR (CI) & $\mathrm{RR}(\mathrm{Cl})$ & $\mathrm{RR}(\mathrm{Cl})$ \\
\hline \multirow[t]{3}{*}{ Both/Both ${ }^{b}$} & 337 & No & 1.00 & $0.87(0.59-1.29)$ & $0.84(0.55-1.29)$ & $1.09(0.73-1.63)$ & $0.93(0.70-1.23)$ \\
\hline & & Age, race $^{c}$ and gender & 1.00 & $0.94(0.64-1.39)$ & $0.73(0.48-1.12)$ & $0.94(0.63-1.41)$ & $0.87(0.66-1.15)$ \\
\hline & & Age, race, gender and others ${ }^{d}$ & 1.00 & $1.11(0.71-1.72)$ & $0.90(0.55-1.45)$ & $1.02(0.65-1.63)$ & $1.01(0.74-1.40)$ \\
\hline
\end{tabular}

\footnotetext{
${ }^{a}$ RRs and Cls for any use estimated as described in additional file 1: Methods for deriving RR estimates.

${ }^{\mathrm{b}}$ Caucasian and African/American people.

c The width of the estimated $\mathrm{Cl}$ is taken to be the same as the width of the unadjusted estimates, so may be slightly too narrow.

${ }^{d}$ The other adjustment factors were total pack-years and years since quitting.
} 
Table 8 Risk of lung cancer by cigarette smoker type - Los Angeles County case-control study [69]

\begin{tabular}{|c|c|c|c|c|c|c|}
\hline \multirow[b]{2}{*}{ Gender/Race } & \multirow[b]{2}{*}{ No of cases } & \multirow[b]{2}{*}{ Adjusted } & \multicolumn{4}{|c|}{ Cigarette smoker type } \\
\hline & & & $\begin{array}{c}\text { Exclusive regular } \\
\text { RR }\end{array}$ & $\begin{array}{c}\text { Exclusive menthol } \\
\text { RR (Cl) }\end{array}$ & $\begin{array}{c}\text { Mixed menthol/regular } \\
\text { RR }(\mathrm{Cl})\end{array}$ & $\begin{array}{c}\text { Any menthol } \\
\text { RR }(\mathrm{Cl})\end{array}$ \\
\hline \multirow[t]{3}{*}{ Both/Both ${ }^{b}$} & 337 & No & 1.00 & $1.17(0.74-1.85)$ & $0.86(0.64-1.17)$ & $0.93(0.70-1.23)$ \\
\hline & & Age, race ${ }^{c}$ and gender & 1.00 & $1.10(0.70-1.74)$ & $0.83(0.61-1.13)$ & $0.89(0.67-1.18)$ \\
\hline & & Age, race, gender and others ${ }^{d}$ & 1.00 & $1.04(0.62-1.75)$ & $1.01(0.71-1.42)$ & $1.02(0.74-1.40)$ \\
\hline
\end{tabular}

the total duration of smoking (assuming that subjects with an unknown brand history before 1956 smoked non-mentholated cigarettes at that time). Analyses used unconditional logistic regression with adjustment for age, gender, race, year of interview and various smoking variables (number of years of smoking, number of cigarettes smoked per day, years since quitting smoking and proportion of years smoking filter cigarettes).

The results shown in Table 9 provide no indication of an effect of mentholation on lung cancer risk. In the most adjusted analyses, RRs show no significant effect of mentholation in males, females, White people or Black people. Overall, ever using mentholated cigarettes is associated with a RR of 0.89 (95\% CI $0.89-1.14)$, and there is no increase for $>15$ years use $(0.97 ; 0.70-1.34)$. In the less adjusted analyses, RRs are always less than
1.00 , and often significant, particularly in the crude analyses. This probably reflects uncontrolled confounding.

Additional analyses (Table 10) found no increased risk of lung cancer according to the proportion of the known smoking history where mentholated cigarettes were used. Nor was any association seen with long term (> 15 years) use of mentholated cigarettes in the alternative analyses shown in Table 11 that included different subsets of smokers (current smokers, smokers of filter cigarettes, smokers with full information on cigarette type) or involved different assumptions concerning missing data on brand history.

The authors concluded that: "The results of this study do not support the hypothesis that smoking menthol cigarettes increases the risk of lung cancer relative to smoking nonmenthol cigarettes."

Table 9 Risk of lung cancer by number of years of smoking mentholated cigarettes among ever smokers for at least 20 years - Slone Epidemiology Center case-control study [53]

\begin{tabular}{|c|c|c|c|c|c|c|}
\hline \multirow[b]{3}{*}{ Gender/Race } & \multirow[b]{3}{*}{ No. of Cases } & \multirow[b]{3}{*}{ Adjusted } & \multicolumn{4}{|c|}{ Years of use of mentholated cigarettes } \\
\hline & & & Never & $1-15$ & $>15$ & Ever $^{a}$ \\
\hline & & & $\mathrm{RR}$ & $\mathrm{RR}(\mathrm{Cl})$ & $\mathrm{RR}(\mathrm{Cl})$ & $\mathrm{RR}(\mathrm{Cl})$ \\
\hline \multirow[t]{3}{*}{ Male/Both } & 435 & $\mathrm{No}^{b}$ & 1.00 & $0.58(0.39-0.86)$ & $0.62(0.42-0.93)$ & $0.60(0.45-0.80)$ \\
\hline & & Age, race $^{c}$ & 1.00 & $0.61(0.41-0.90)$ & $0.71(0.48-1.06)$ & $0.66(0.49-0.88)$ \\
\hline & & Age, race and others ${ }^{d}$ & 1.00 & $0.67(0.43-1.05)$ & $0.91(0.57-1.46)$ & $0.77(0.55-1.08)$ \\
\hline \multirow[t]{3}{*}{ Female/Both } & 208 & $\mathrm{No}^{\mathrm{b}}$ & 1.00 & $0.670 .42-1.09)$ & $0.75(0.51-1.11)$ & $0.72(0.52-1.00)$ \\
\hline & & Age, race ${ }^{c}$ & 1.00 & $0.76(0.47-1.23)$ & $0.89(0.60-1.32)$ & $0.84(0.60-1.16)$ \\
\hline & & Age, race and others ${ }^{d}$ & 1.00 & $1.14(0.66-1.95)$ & $1.00(0.63-1.60)$ & $1.05(0.72-1.55)$ \\
\hline \multirow[t]{3}{*}{ Both/White people } & 515 & $\mathrm{No}^{\mathrm{b}}$ & 1.00 & $0.69(0.49-0.98)$ & $0.71(0.50-1.01)$ & $0.70(0.54-0.91)$ \\
\hline & & Age, gender ${ }^{c}$ & 1.00 & $0.71(0.50-1.01)$ & $0.87(0.61-1.24)$ & $0.78(0.60-1.01)$ \\
\hline & & Age, gender and others ${ }^{d}$ & 1.00 & $0.86(0.59-1.28)$ & $1.01(0.68-1.51)$ & $0.93(0.69-1.24)$ \\
\hline \multirow[t]{3}{*}{ Both/Black people } & 128 & $\mathrm{No}^{\mathrm{b}}$ & 1.00 & $0.40(0.21-0.74)$ & $0.50(0.32-0.79)$ & $0.46(0.31-0.69)$ \\
\hline & & Age, gender ${ }^{c}$ & 1.00 & $0.52(0.28-0.97)$ & $0.69(0.44-1.09)$ & $0.63(0.42-0.94)$ \\
\hline & & Age, gender and others ${ }^{d}$ & 1.00 & $0.60(0.27-1.35)$ & $1.21(0.64-2.26)$ & $0.91(0.52-1.59)$ \\
\hline \multirow[t]{3}{*}{ Both/Both } & 643 & $\mathrm{No}^{\mathrm{b}}$ & 1.00 & $0.59(0.43-0.79)$ & $0.60(0.46-0.79)$ & $0.59(0.48-0.74)$ \\
\hline & & Age, race and gender ${ }^{c}$ & 1.00 & $0.65(0.48-0.88)$ & $0.76(0.58-1.00)$ & $0.70(0.57-0.88)$ \\
\hline & & Age, race, gender and others ${ }^{d}$ & 1.00 & $0.80(0.57-1.13)$ & $0.97(0.70-1.34)$ & $0.89(0.69-1.14)$ \\
\hline
\end{tabular}

\footnotetext{
${ }^{a}$ Except for the final estimates in this column, all RRs and Cls were derived as described in additional file 1: Methods for deriving RR estimates.

${ }^{b}$ All unadjusted RRs and Cls were derived as described in additional file 1: Methods for deriving RR estimates.

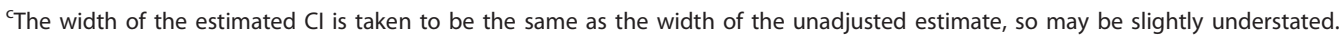

$\mathrm{d}$ The other adjustment factors were year at interview, duration of smoking, cigarettes per day, years since quitting and proportion of years smoked filter cigarettes.
} 
Table 10 Risk of lung cancer by proportion of known smoking history smoking mentholated cigarettes among ever smokers - Slone Epidemiology Center case-control study [53]

\begin{tabular}{|c|c|c|c|c|c|}
\hline \multirow[b]{3}{*}{ Gender/Race } & \multirow[b]{3}{*}{ No. of cases } & \multirow[b]{3}{*}{ Adjusted } & \multicolumn{3}{|c|}{ Proportion of smoking history } \\
\hline & & & None & $1-49 \%$ & $50 \%$ \\
\hline & & & RR & $\mathrm{RR}(\mathrm{Cl})$ & RR (Cl) \\
\hline \multirow[t]{3}{*}{ Both/Both } & 642 & $\mathrm{No}^{\mathrm{a}}$ & 1.00 & $0.86(0.62-1.18)$ & $0.49(0.37-0.63)$ \\
\hline & & Age, race and gender ${ }^{\mathrm{b}}$ & 1.00 & $0.81(0.59-1.12)$ & $0.63(0.48-0.82)$ \\
\hline & & Age, race, gender and others ${ }^{c}$ & 1.00 & $0.86(0.59-1.24)$ & $0.89(0.65-1.22)$ \\
\hline
\end{tabular}

a All unadjusted RRs and Cls were derived as described in additional file 1: Methods for deriving RR estimates.

${ }^{\mathrm{b}}$ The width of the estimated $\mathrm{Cl}$ is taken to be the same as the width of the unadjusted estimate, so may be slightly understated.

c The other adjustment factors were year at interview, duration of smoking, cigarettes per day, years since quitting and proportion of years smoked filter cigarettes.

\section{Second American Health Foundation multicentre case- control study}

The fifth paper providing relevant results [83] was reported in 2003. Unlike the previous papers, which were primarily concerned with risk of lung cancer in relation to mentholated cigarette use, the main objective of this paper was to compare risk in White and Black Americans. As for the first paper [68], it was based on data from the American Health Foundation multicentre hospital case-control study, though the subjects were interviewed between 1984 and 1998 (rather than between 1985 and 1990) and the hospitals involved were not exactly the same. The controls were hospitalized patients with conditions thought not to be associated with smoking, and were matched to the cases on age, gender, hospital and year of interview. The study involved 1964 male and 1484 female histologically confirmed cases interviewed within a year of diagnosis, and 4931 male and 3220 female controls. Information relating to mentholation was limited to whether current smokers preferred mentholated cigarettes or not, with data available for an estimated 963 male and 803 female cases and 1098 male and 572 female controls (assuming this information was available for all the current smokers).

The authors reported RRs (CIs) for menthol preference separately by gender and race, none of which were statistically significant. These were adjusted for age, education, body mass index and pack-years. Table 12 includes these estimates, and also additional derived estimates. The unadjusted estimates, and those adjusted for gender and/or race are all under 1.00. Additional adjustment for age, education, body mass index and pack-years increased the RR somewhat, but none were significant, and most under 1.00. For the overall data, combined over genders and races, the most-adjusted RR estimate was 0.83 (CI 0.68-1.02).

The authors noted that: "Smokers of menthol flavored cigarettes were at no greater risk for lung cancer than were smokers of unflavored brands."

\section{German case-control study}

The sixth study with relevant findings was reported as an abstract in 2004 [84]. Unusually, this study was conducted in Germany, in a white population. The study was a hospital-based case-control study involving incident lung cancer cases (839 males and 165 females) and the same number of population controls matched for region, gender and age. Subjects were interviewed about their smoking history including brand names, and ever use of mentholated cigarettes was determined. After adjustment for total amount of tobacco smoking and also for the matching variables, via conditional logistic regression, the RR for ever smoking menthol cigarettes was 1.12 (CI $0.68-1.83$ ). $5 \%$ of the cases and $4 \%$ of the

Table 11 Other estimates for risk of lung cancer for > 15 years of mentholated cigarette smoking - Slone Epidemiology Center case-control study [53]

\begin{tabular}{|c|c|c|}
\hline Analysis & Adjusted & $\mathrm{RR}(\mathrm{Cl})$ \\
\hline In current smokers & Age, race, gender and others ${ }^{a}$ & $0.90(0.62-1.31)$ \\
\hline In smokers of filter cigarettes & Age, race, gender and others ${ }^{a}$ & $0.95(0.58-1.58)$ \\
\hline In smokers with full information on cigarette type & Age, race, gender and others ${ }^{a}$ & $0.70(0.38-1.29)$ \\
\hline $\begin{array}{l}\text { Assuming smokers smoked mentholated cigarettes } \\
\text { where brand history unknown }\end{array}$ & Age, race, gender and others ${ }^{a}$ & $0.95^{b}$ \\
\hline Assuming proportion of menthol use same when brand & Age, race, gender and others ${ }^{a}$ & $0.88^{b}$ \\
\hline
\end{tabular}
history not known as when brand history is known

${ }^{a}$ The other adjustment factors were year at interview, duration of smoking, cigarettes per day, years since quitting and proportion of years smoked filter cigarettes.

${ }^{\mathrm{b}} \mathrm{Cl}$ were not provided. 
Table 12 Risk of lung cancer in current smokers according to preference for mentholated cigarettes Second American Health Foundation multicentre casecontrol study [83]

\begin{tabular}{|c|c|c|c|c|}
\hline Gender & Race & $\begin{array}{l}\text { No. of } \\
\text { cases }\end{array}$ & Adjusted & $\mathrm{RR}(\mathrm{Cl})$ \\
\hline \multirow[t]{7}{*}{ Male } & $\begin{array}{l}\text { White } \\
\text { people }\end{array}$ & 799 & None $^{a}$ & $0.79(0.61-1.01)$ \\
\hline & & & Others $^{\mathrm{b}}$ & $0.83(0.63-1.09)$ \\
\hline & $\begin{array}{l}\text { Black } \\
\text { people }\end{array}$ & 164 & None $^{a}$ & $0.72(0.46-1.11)$ \\
\hline & & & Others $^{\mathrm{b}}$ & $1.34(0.79-2.29)$ \\
\hline & Combined & 963 & None $^{a}$ & $0.80(0.65-0.99)$ \\
\hline & & & Race $^{a}$ & $0.77(0.62-0.96)$ \\
\hline & & & Race, others ${ }^{a, b}$ & $0.92(0.72-1.17)$ \\
\hline \multirow[t]{7}{*}{ Female } & $\begin{array}{l}\text { White } \\
\text { people }\end{array}$ & 701 & None $^{a}$ & $0.50(0.37-0.68)$ \\
\hline & & & Others $^{\mathrm{b}}$ & $0.61(0.44-1.06)$ \\
\hline & $\begin{array}{l}\text { Black } \\
\text { people }\end{array}$ & 102 & None $^{a}$ & $0.66(0.38-1.16)$ \\
\hline & & & Others $^{\mathrm{b}}$ & $0.79(0.41-1.54)$ \\
\hline & Combined & 803 & None $^{a}$ & $0.52(0.40-0.67)$ \\
\hline & & & Race $^{a}$ & $0.53(0.41-0.70)$ \\
\hline & & & Race, others ${ }^{a, b}$ & $0.66(0.46-0.95)$ \\
\hline \multirow[t]{9}{*}{ Combined } & $\begin{array}{l}\text { White } \\
\text { people }\end{array}$ & 1500 & None $^{a}$ & $0.66(0.54-0.80)$ \\
\hline & & & Gender $^{\mathrm{a}}$ & $0.65(0.54-0.79)$ \\
\hline & & & Others ${ }^{\mathrm{a}, \mathrm{b}}$ & $0.76(0.60-0.96)$ \\
\hline & $\begin{array}{l}\text { Black } \\
\text { people }\end{array}$ & 266 & None $^{a}$ & $0.70(0.49-0.98)$ \\
\hline & & & Gender $^{\mathrm{a}}$ & $0.70(0.49-0.98)$ \\
\hline & & & Others ${ }^{a, b}$ & $1.09(0.72-1.65)$ \\
\hline & Combined & 1766 & None $^{a}$ & $0.68(0.57-0.80)$ \\
\hline & & & Gender, race ${ }^{a}$ & $0.66(0.56-0.79)$ \\
\hline & & & $\begin{array}{l}\text { Gender, race, } \\
\text { others }{ }^{a, b}\end{array}$ & $0.83(0.68-1.02)$ \\
\hline
\end{tabular}

${ }^{a}$ RRs and Cls were derived as described in additional file 1: Methods for deriving RR estimates.

${ }^{\mathrm{b}}$ The other adjustment factors were age, education, body mass index and pack-years.

controls had ever smoked mentholated cigarettes, implying an unadjusted RR of 1.26 (0.83-1.93).

It is not stated in the abstract whether the study was restricted to current smokers or ever smokers or if it included never smokers as well. The analysis would not seem to make sense unless it was restricted to current smokers or ever smokers. As the endpoint is ever use of mentholated cigarettes, it seems likely that the study concerned ever smokers.

The authors comment that "The present study gives no indication for an additional risk of ever smoking mentholated cigarettes if total amount of smoking is taken into account. However, the number of exposed subjects is small hindering definite conclusions with respect to dose."

\section{Lung health prospective study}

The seventh paper to report results [56] was published in 2007. It was based on data from the Lung Health Study which, in 1986 to 1989 , enrolled 3698 male and 2185 female smokers aged 35-60 years with mild to moderate airways obstruction in a clinical trial of smoking cessation. 1961 were randomly assigned to usual care, and 3922 to one of two special interventions (smoking intervention plus either an anticholinergic bronchodilator or a placebo inhaler). The intervention took place over a five-year period, with a follow-up at year 11 and surveillance for mortality to year 14 . At baseline and at subsequent annual visits, subjects still smoking were asked "What type of cigarettes are they? Are they plain or menthol?".

The authors reported the results of Cox regression analyses adjusted for age, gender, baseline cigarettes/day, $\mathrm{FEV}_{1}$ (as percentage of predicted), randomization group, race and baseline years of education for various causes of death. For lung cancer, based on 240 deaths, the RR for smoking mentholated cigarettes at baseline was estimated as 0.96 (CI 0.70-1.32). No relationship was also seen with mortality from any cause $(0.997,0.83-1.20)$, coronary heart disease $(1.31,0.77-2.22)$, or cardiovascular disease (1.03, 0.70-1.52). No further lung cancer RRs can be derived from the data presented.

The authors concluded that "our data contain no evidence that mentholation of cigarettes increases the hazards of smoking."

\section{Houston case-control study}

The final paper [85], published in 2008, was concerned with the development of a lung cancer prediction model for Black people. It was based on a case-control study conducted in hospitals in Houston from 1995 to 2005. The cases were newly/recently diagnosed, histopathologically confirmed, untreated lung cancers without prior chemotherapy, radiotherapy or recent blood transfusion. Controls, matched to the cases on age, gender and race, came from community centres and a multispecialty physicians' group practice. The analysis focused on cases (294 males and 197 females) and controls (244 males and 253 females) who reported being Black (AfricanAmerican) people. Analyses of mentholated cigarette use were conducted separately in current smokers and in former smokers.

As shown in Table 13, there was no evidence of an increased risk associated with mentholated cigarette use in any analysis. After adjustment for age, gender and smoking status (current/former smoker), the RR was estimated as 0.81 (0.60-1.09). The authors also noted that, in current smokers, the reduced RR associated with mentholated use $(0.69,0.46-1.03)$ was non-significant, and remained so after stratification by pack-years. They also reported results of multivariate risk modelling 
Table 13 Risk of lung cancer according to mentholated cigarette use - Houston case-control study [85]

\begin{tabular}{|c|c|c|c|}
\hline Smoking habits & Cases & Adjusted & $\mathrm{RR}(\mathrm{Cl})$ \\
\hline \multirow[t]{2}{*}{ Current smokers } & 278 & None $^{a}$ & $\begin{array}{l}0.63(0.43- \\
0.93)\end{array}$ \\
\hline & & Age, gender & $\begin{array}{l}0.69(0.46- \\
1.03)\end{array}$ \\
\hline \multirow[t]{2}{*}{ Former smokers } & 176 & None $^{a}$ & $\begin{array}{l}0.76(0.50- \\
1.17)\end{array}$ \\
\hline & & Age, gender & $\begin{array}{l}0.99(0.62- \\
1.56)\end{array}$ \\
\hline \multirow[t]{3}{*}{$\begin{array}{l}\text { Current and former } \\
\text { smokers }\end{array}$} & 454 & None $^{a}$ & $\begin{array}{l}0.72(0.54 \\
0.95)\end{array}$ \\
\hline & & Smoking status ${ }^{a}$ & $\begin{array}{l}0.69(0.52- \\
0.91)\end{array}$ \\
\hline & & $\begin{array}{l}\text { Age, gender, smoking } \\
\text { status }^{\mathrm{a}}\end{array}$ & $\begin{array}{l}0.81(0.60- \\
1.09)\end{array}$ \\
\hline
\end{tabular}

${ }^{a}$ RRs and Cls were derived as described in additional file 1: Methods for deriving RR estimates.

involving a range of risk factors for lung cancer. Variables retained in the final model were smoking status, pack-years of smoking, age at smoking cessation, exposure to asbestos or dusts, and history of COPD or hay fever, but not use of mentholated cigarettes.

The authors noted that "In our analysis, we observed no significant risks of lung cancer among former or current smokers who reported smoking mentholated cigarettes (OR range 0.69-0.99), and our data suggested a possible protective effect of mentholated cigarettes for current smokers."

\section{Study characteristics, strengths and weaknesses}

The main features of the eight studies are presented in Table 14 and summarized in Table 15 . These features are discussed below, with comments where relevant on the strengths and weaknesses of the studies.

\section{Study type}

The eight studies covered the three most common types of design used in epidemiological research, with two prospective cohort studies $[51,56]$, three hospital casecontrol studies $[53,68,83]$ and three population casecontrol studies $[69,84,85]$. One of the cohort studies [56] was based on follow-up subjects entering a clinical trial. The prospective design virtually excludes the possibility of recall bias. However, both such studies based their analysis on use of mentholation at baseline, which could be over 10 years before the lung cancer occurred, and might have changed during the follow-up period. Neither of these studies concerned representative samples. The clinical trial [56] concerned subjects with mild or moderate airways obstruction, while subjects in the Kaiser Permanente study [51] had to attend for multiphasic health check-up and were noted to be somewhat more educated than the local population and under- representative of the extremes of wealth and poverty. However, any differential risk of mentholated and nonmentholated cigarettes seems unlikely to vary by education, income or prevalence of airway obstruction, so bias should not occur. While case-control studies suffer from the problem that exposure is determined after onset of disease, it is unclear, however, why accuracy of reporting relative use of mentholated and non-mentholated cigarettes should differ materially between lung cancer cases and controls.

\section{Location}

All but one of the studies were conducted in the United States. The study in Germany [84], reported as an abstract, involved a population where mentholated cigarette use is quite low, and its results, based on a relatively small number of lung cancer cases in mentholated cigarette smokers, contribute relatively little to the meta-analyses described later.

\section{Timing}

The studies considered started between 1979 and 1995. Inasmuch as mentholated cigarettes only reached an appreciable market share in the 1960s and 1970s, one might expect studies starting later to have more chance of detecting possible effects. However, data by period of mentholated cigarette use were only reported in the first four reported studies $[51,53,68,69]$, limiting the ability to determine lung cancer risk for very long term (e.g. 40+ years) use. However, any major difference in risk between the two types of cigarette might be expected to emerge in the studies so far conducted.

\section{Possible overlaps between the studies}

It is clear from the information on study location and timing in Table 14, that double-counting of cases is only a possible problem for the three hospital case-control studies. Though the range of years and hospitals varied between the studies, it is likely that there was some overlap in the patients considered. Without reference back to the original data, there is no completely satisfactory solution to this. To avoid loss of power, our main analyses include the data from all the studies, ignoring the overlap, though it is recognized that this may slightly overstate statistical significance. However, as a sensitivity test, some analyses were also run excluding the results from two of these three studies, the first American Health Foundation Study [68] and the Slone Epidemiology Center Study [53], only retaining results from the second American Health Foundation Study [83], the study with the largest number of lung cancer cases in mentholated cigarette smokers.

\section{Number of cases and power to detect an effect}

The number of cases considered in the analyses ranged from 240 in the Lung Health study [56] to 1766 in the second American Health Foundation multicentre study [83]. Four studies involved over 500 cases and three 
Table 14 Main features of the epidemiological studies of cigarette mentholation and lung cancer

\begin{tabular}{|c|c|c|c|c|}
\hline Characteristics & $\begin{array}{l}\text { 1. American Health } \\
\text { Foundation study }\end{array}$ & $\begin{array}{l}\text { 2. Kaiser } \\
\text { Permanente } \\
\text { study }\end{array}$ & 3. Los Angeles County study & 4. Slone Epidemiology Center study \\
\hline Source & $\begin{array}{l}\text { Kabat and Hebert (1991) } \\
\text { [68] }\end{array}$ & $\begin{array}{l}\text { Sidney et al. } \\
\text { (1995) [51] }\end{array}$ & Carpenter et al. (1999) [69] & Brooks et al. (2003) [53] \\
\hline Study design & Hospital case-control & $\begin{array}{l}\text { Prospective } \\
\text { cohort }\end{array}$ & Population case-control & Hospital case-control \\
\hline Location & $\begin{array}{l}\text { USA; New York, } \\
\text { Chicago, Detroit, } \\
\text { Philadelphia }\end{array}$ & $\begin{array}{l}\text { USA; } \\
\text { Oakland, } \\
\text { California }\end{array}$ & USA; Los Angeles County, California & $\begin{array}{l}\text { USA; New York, Philadelphia, Massachusetts, } \\
\text { Maryland }\end{array}$ \\
\hline Timing & 1985-1990 & $\begin{array}{l}1979-1985 \\
\text { followed to } \\
1991\end{array}$ & 1991-1994 & $1981-2000$ \\
\hline Gender & Both & Both & Both & Both \\
\hline Age & Unrestricted & $\begin{array}{l}30 \text { to } 89 \\
\text { years at } \\
\text { baseline }\end{array}$ & 40 to 84 years & 40 to 74 years \\
\hline Smoking & Current smokers & $\begin{array}{l}\text { Current } \\
\text { smokers (for } \\
20+\text { years) }\end{array}$ & Ever smoked & Ever smoked (for $20+$ years) \\
\hline $\begin{array}{l}\text { Other inclusion } \\
\text { criteria }\end{array}$ & None stated & None stated & $\begin{array}{l}\text { Caucasian (non-Hispanic) or African- } \\
\text { American people; no previous cancer }\end{array}$ & $\begin{array}{l}\text { Menthol details for } 60 \% \text { of smoking history; } \\
\text { no history of cancer }\end{array}$ \\
\hline Cases & $1044(588 \mathrm{M}, 456 \mathrm{~F})$ & $\begin{array}{l}318(168 \mathrm{M} \\
150 \mathrm{~F})\end{array}$ & $337(202 \mathrm{M}, 135 \mathrm{~F})$ & $643(435 \mathrm{M}, 208 \mathrm{~F})$ \\
\hline $\begin{array}{l}\text { Cases in } \\
\text { mentholated } \\
\text { cig smokers }\end{array}$ & 259 & 93 & 151 & 114 \\
\hline $\begin{array}{l}\text { Definition of } \\
\text { cases }\end{array}$ & $\begin{array}{l}\text { Histologically confirmed, } \\
\text { interviewed within } 2 \\
\text { months of diagnosis }\end{array}$ & Incident & $\begin{array}{l}\text { Histologically confirmed, interviewed } \\
\text { within } 7 \text { months of diagnosis }\end{array}$ & $\begin{array}{l}\text { Confirmed by pathology, interviewed within } \\
12 \text { months of diagnosis }\end{array}$ \\
\hline At risk & Not applicable & $5771 \mathrm{M}, 5990 \mathrm{~F}$ & Not applicable & Not applicable \\
\hline Controls & 1324 (914M, 410F) & $\begin{array}{l}\text { Not } \\
\text { applicable }\end{array}$ & 478 (349M, 129F) & 4110 (2123M, 1987F) \\
\hline $\begin{array}{l}\text { Definition of } \\
\text { controls }\end{array}$ & $\begin{array}{l}\text { Diseases unrelated to } \\
\text { smoking }\end{array}$ & $\begin{array}{l}\text { Not } \\
\text { applicable }\end{array}$ & $\begin{array}{l}\text { Licensed drivers (age < } 65 \text { ) and Medicare } \\
\text { beneficiaries (age } 65+\text { ) }\end{array}$ & Diseases unrelated to smoking \\
\hline $\begin{array}{l}\text { Matching of } \\
\text { controls }\end{array}$ & $\begin{array}{l}\text { Age, gender, race, } \\
\text { hospital, date of } \\
\text { interview }\end{array}$ & $\begin{array}{l}\text { Not } \\
\text { applicable }\end{array}$ & Age, gender, race & No matching \\
\hline $\begin{array}{l}\text { Menthol } \\
\text { variable }\end{array}$ & $\begin{array}{l}\text { Time used }(<1,1-14,15 \\
+ \text { yrs })\end{array}$ & $\begin{array}{l}\text { Time used }(0, \\
1-9,10-19,20 \\
+y r s)\end{array}$ & $\begin{array}{l}\text { Pack-years menthol }(0,1-15,16-31,32+), \% \\
\text { menthol }(0,1-19,20-74,75-100) \text {, cig type } \\
\text { (regular only, menthol only, mixed) }\end{array}$ & $\begin{array}{l}\text { Time used }(0,1-15,>15 \text { years), \% years } \\
\text { smoked }(0,1-49,50-100)\end{array}$ \\
\hline $\begin{array}{l}\text { Adjustment for } \\
\text { race }\end{array}$ & Yes & Yes & Yes & Yes \\
\hline $\begin{array}{l}\text { Adjustment for } \\
\text { smoking habits }\end{array}$ & $\begin{array}{l}\text { Cigs/day, inhalation, } \\
\text { duration }\end{array}$ & $\begin{array}{l}\text { Cigs/day, } \\
\text { duration }\end{array}$ & Total pack-years, years since quitting & $\begin{array}{l}\text { Cigs/day, duration, years since quitting, time } \\
\text { used filter cigarettes }\end{array}$ \\
\hline $\begin{array}{l}\text { Adjustment for } \\
\text { other variables }\end{array}$ & $\begin{array}{l}\text { Age, gender, education, } \\
\text { body mass index }\end{array}$ & $\begin{array}{l}\text { Age, gender, } \\
\text { education }\end{array}$ & Age, gender ${ }^{a}$ & Age, gender, year of interview \\
\hline $\begin{array}{l}\text { Results by } \\
\text { histological } \\
\text { type }\end{array}$ & $\begin{array}{l}\text { Squamous cell, small } \\
\text { cell, large cell, } \\
\text { adenocarcinoma }\end{array}$ & No & No & No \\
\hline Study quality ${ }^{b}$ & 5 & 9 & 7 & 6 \\
\hline Characteristics & $\begin{array}{l}\text { 5. Second American } \\
\text { Health Foundation } \\
\text { study }\end{array}$ & $\begin{array}{l}\text { 6. German } \\
\text { study }\end{array}$ & 7. Lung Health study & 8. Houston study \\
\hline Source & $\begin{array}{l}\text { Stellman et al. (2003) } \\
\text { [83] }\end{array}$ & $\begin{array}{l}\text { Jöckel et al. } \\
\text { (2004) [84] }\end{array}$ & Murray et al. (2007) [56] & Etzel et al. (2008) [85] \\
\hline Study design & Hospital case-control & $\begin{array}{l}\text { Population } \\
\text { case-control }\end{array}$ & Prospective clinical trial & Population case-control \\
\hline Location & $\begin{array}{l}\text { USA; New York, } \\
\text { Chicago, Hines, Detroit, } \\
\text { Philadelphia }\end{array}$ & $\begin{array}{l}\text { Germany; } \\
\text { location not } \\
\text { known }\end{array}$ & USA and Canada; 10 centres & USA; Houston \\
\hline
\end{tabular}


Table 14 Main features of the epidemiological studies of cigarette mentholation and lung cancer (Continued)

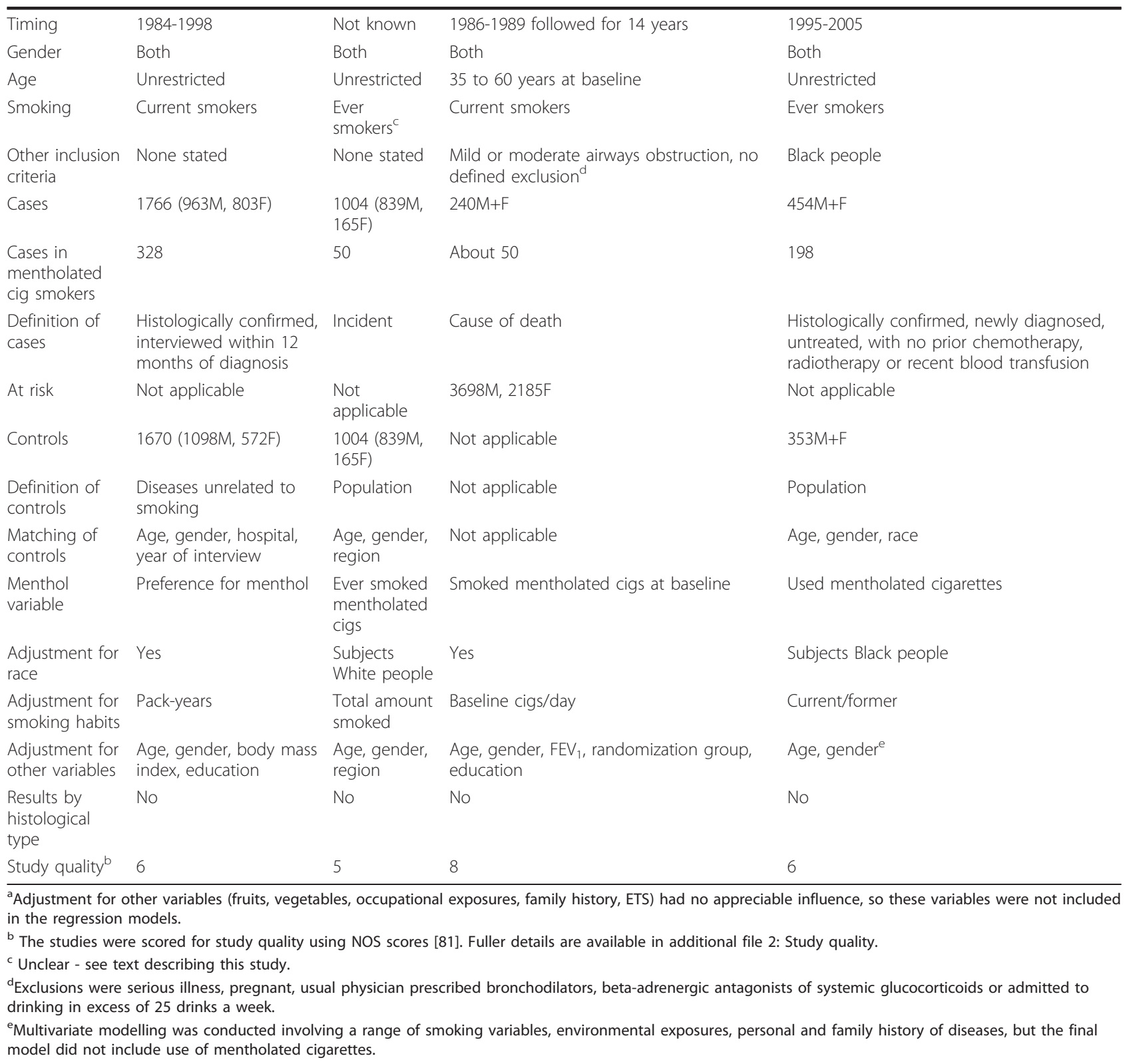

over 1000. All studies involved both males and females. The proportion of those cases which reported use of mentholated cigarettes was only $4 \%$ in the German study [84] but was much higher in the US studies, varying from about $20 \%$ in three studies $[53,56,83]$ to over $40 \%$ in two $[69,85]$. This variation would depend on the actual questions asked and where the study was conducted. One of the studies [85] was conducted in Black people. Based on the most adjusted results for the total population studied, all the US studies would have detected as significant, at the $95 \%$ confidence interval, an excess risk associated with mentholated cigarette smoking of between $20 \%$ and $40 \%$. The German study was less powerful and would only have detected an excess risk of about $65 \%$.

\section{Adequacy of the cases}

Five of the case-control studies confirmed the diagnosis by histology/pathology, but the German case-control study [84] gave no details. In all these studies, the lung cancer was recently diagnosed. One of the cohort studies [51] gave no information regarding diagnosis of their incident cases, but the other [56], which only considered deaths, classified cause of death based on a review of death certificates, autopsy reports, relevant medical records, and interviews with attending physicians. There is abundant evidence that an in-life 
Table 15 Summary of the main features of the epidemiological studies of cigarette mentholation and lung cancer

\begin{tabular}{|c|c|c|c|c|c|}
\hline Characteristic & Level & $\mathrm{N}(\%)$ & Characteristic & Level & N (\%) \\
\hline \multirow[t]{5}{*}{ Study design } & & & Cases in mentholated cigarette smokers & & \\
\hline & Prospective cohort & $2(25.0)$ & & $50-124$ & $4(50.0)$ \\
\hline & Hospital case-control & $3(37.5)$ & & $125+$ & $4(50.0)$ \\
\hline & Population case-control & $3(37.5)$ & & & \\
\hline & & & Controls matched on age and gender & & \\
\hline \multirow[t]{3}{*}{ Country } & & & & Yes & $5(62.5)$ \\
\hline & USA & $7(87.5)$ & & No & $1(12.5)$ \\
\hline & Germany & $1(12.5)$ & & Prospective & $2(25.0)$ \\
\hline \multirow[t]{5}{*}{ First year of study } & & & Menthol dose-response studied & & \\
\hline & 1979 to 1985 & $3(37.5)$ & & Yes & $4(50.0)$ \\
\hline & 1986 to 1995 & $4(50.0)$ & & No & $4(50.0)$ \\
\hline & Not known & $1(12.5)$ & & & \\
\hline & & & Race accounted for & & \\
\hline \multirow[t]{4}{*}{ Year of publication } & & & & Yes & $8(100.0)$ \\
\hline & 1991 to 2000 & $3(37.5)$ & & & \\
\hline & 2001 to 2008 & $5(62.5)$ & Smoking adjusted for & & \\
\hline & & & & Yes & $8(100.0)$ \\
\hline \multicolumn{6}{|l|}{ Genders studied } \\
\hline & Both & $8(100.0)$ & & & \\
\hline & & & Age adjusted for & Yes & $8(100.0)$ \\
\hline \multicolumn{6}{|c|}{ Smoking groups used in analysis } \\
\hline & Current & $4(50.0)$ & Results by histological type & Yes & $1(12.5)$ \\
\hline & Ever & $4(50.0)$ & & No & $7(87.5)$ \\
\hline \multicolumn{6}{|l|}{ Cases studied } \\
\hline & $200-499$ & $4(50.0)$ & NOS study quality score & 7 to 9 & $3(37.5)$ \\
\hline & $500-999$ & $1(12.5)$ & & 5 to 6 & $5(62.5)$ \\
\hline & $1000+$ & $3(37.5)$ & & & \\
\hline
\end{tabular}

diagnosis of lung cancer is unconfirmed by autopsy diagnosis in a moderate proportion (perhaps $10 \%$ or so) of cases [86]. Since only one of the studies [56] seemed to consider autopsy evidence, it is likely that some of the cases included were false-positives. However, the procedures taken in most, if not all, of the studies would have greatly reduced this possibility. Although knowledge of smoking habits may affect the likelihood of a lung cancer being detected in life $[87,88]$, it seems implausible that knowledge of mentholation status would do so. It is therefore unlikely that inaccuracy of diagnosis will have had any material effect in these studies.

\section{Adequacy of the controls}

The three hospital case-control studies $[53,68,83]$ used patients with diseases unrelated to smoking as controls. The descriptions of the controls used were as follows:

American Health Foundation Study [68] "Controls were hospitalized patients with conditions thought not be associated with smoking, including: cancers (of the colon, stomach, female breast, prostate, and skin, as well as leukaemia, lymphoma, sarcomas, etc.); benign neoplastic diseases; and non-neoplastic conditions (such as musculoskeletal and connective tissue disorders, eye conditions, injuries, etc.)."

Slone Epidemiology Center study [53] "Controls had been admitted for conditions judged to be unrelated to cigarette smoking. The most common control diagnoses included cancers or benign tumors of the breast, colon and rectum, prostate, and other non-tobacco-related sites (45 percent); diseases of the digestive (14 percent), genitourinary (10 percent), or musculoskeletal (7 percent) systems; and injury (13 percent). Respiratory or upper gastrointestinal conditions, regardless of etiology, were excluded."

Second American Health Education Study [83] "Eligible control diagnoses excluded tobacco-related diseases such as coronary heart disease, stroke, peripheral vascular disease, chronic obstructive pulmonary disease, gastric ulcer, cirrhosis of the liver, and cancers of the mouth, larynx, esophagus, bladder, kidney, pancreas, or liver." They go on to note the percentage of male and female controls with specific diseases.

When discussing the first of these three studies [68], Sidney et al. [51] claimed that "some of these conditions might have been associated with menthol use, obscuring 
an association with lung cancer". However, it seems rather unlikely that a disease that is not affected by smoking non-mentholated cigarettes would be affected by smoking mentholated cigarettes. Risk of some of the cancers (stomach, breast, and perhaps colon) may, according to recent evidence, be moderately associated with smoking. However, as they form only a proportion of the total controls, and may not be related to menthol use anyway, it seems unlikely that their inclusion would have caused material bias.

Of the three population case-control studies $[69,84,85]$, the one conducted in Germany [84] was reported only as an abstract with no details given of how the controls were derived.

In the Los Angeles county study [69], the population controls used were derived from registers of licensed drivers aged under 65 and of Medicare Beneficiaries aged over 65 . However, there seems no guarantee that cases aged under 65 could drive or that cases aged over 65 used Medicare. If ability to drive or use of Medicare is associated with use of mentholated cigarettes, some bias might occur.

In the Houston study of Black people [85], the cases and controls were drawn only from the metropolitan area of Houston. While the cases were recruited "from the University of Texas M.D. Anderson Cancer Center and the Michael E. De Bakey VA Medical Center", the controls were recruited "from Houston area community centers and the Kelsey-Seybold Clinic, Houston's largest multispeciality physicians group practice". It is not apparent how representative the controls were of the population from which the cases were drawn.

In both these studies there was no clear difference in response rate between cases and controls. This was stated to be about $75 \%$ in both cases and controls in the Houston study [85] and can be estimated as 70\% in cases and $75 \%$ in controls in the Los Angeles County study [69]. Response rates were not given for the German study [84] or for two of the case-control studies $[53,68]$, but in the second American Health Foundation study [83], it was noted that "approximately $85 \%$ of eligible patients who were approached agreed to be interviewed", though separate figures for cases and controls were not given.

\section{Reliability of the data collected}

All the studies are limited by possible inaccuracies in the reporting of smoking history and mentholation status. Random errors tend to bias relative risk estimates towards 1.0 and reduce the power of the study to detect a true effect. However, errors may not be random. For example, subjects may tend to think their past habits were more like their current habits than they actually were.
The source of the data on mentholation is summarized in Table 16. As can be seen, this varies from study to study. Four of the studies $[51,53,68,84]$ were asked about brand smoked. In two of these studies [51,53], subjects were also asked whether they smoked mentholated cigarettes but no mention is made of any crosscheck being made with the brands reported. One of the studies reporting results for ever smokers [53] only asked about the most recent brand and that used for the longest period, resulting in incomplete information on mentholated cigarette use for many subjects.

The effect that error in determining mentholation status might have had on the relative risk estimates is not clear. Inasmuch as mentholated cigarettes have a distinctive taste, any errors may not be too great.

In the Slone Epidemiology Center study [53], subjects with an unknown brand history before 1956 were assumed to have smoked non-mentholated cigarettes at that time. This would probably have led to some overestimation of the numbers of non-mentholated cigarette smokers and slightly reduced the power to detect effects of mentholation. However, as the assumption applied equally to cases and controls, this is unlikely to have caused material bias.

\section{Adjustment for potential confounding variables}

Except for the German study [84] and the Houston study of Black people [85], all the studies either adjusted for race, or presented race-specific results from which race-adjusted overall results could be calculated. All the studies adjusted for age, and all either adjusted for gender or presented results from which gender-adjusted overall results could be calculated.

All the studies adjusted for smoking variables, with three studies adjusting for cigarettes per day and duration of smoking $[51,53,68]$ and three studies adjusting for indices of total exposure - pack-years $[69,83]$ or total amount smoked [84]. Some of these six studies adjusted for additional variables: inhalation [68], time used filter cigarettes [53] and in two studies of ever (rather than current) smokers, years since quitting [53,69]. The most limited adjustments are in the Lung Health study [56] which only adjusted for baseline cigarettes/day, the Houston study [85], where results were only available adjusted for current/former smoking, and the German study [84], which appeared to present results for ever smokers but only adjusted for total amount smoked, without taking quitting into account.

Education was adjusted for in four studies $[51,56,68,83]$ and body mass index in two $[68,83]$, with other variables adjusted for being year of interview [53] and $\mathrm{FEV}_{1}$ and randomization group [56]. It is of interest that none of the studies adjusted for occupational exposure, which one might expect to vary by mentholated 


\begin{tabular}{ll}
\hline Study & Data collected \\
\hline American Health Foundation study & $\begin{array}{l}\text { Subjects were asked about lifetime history of brands of cigarettes smoked (up to } 7 \text { brands per person) and } \\
\text { [68] }\end{array}$ \\
information was obtained on whether all brands reported were mentholated or not. If the brand name could \\
Kaiser Permanente study [51] & $\begin{array}{l}\text { Subjects were asked about the brand of the cigarette currently smoked and on whether the brand was } \\
\text { mentholated or not. The authors did not report that they had obtained information on which brands were } \\
\text { mentholated, or that they had checked one answer against the other. }\end{array}$ \\
Los Angeles County study [69] & $\begin{array}{l}\text { Mentholated cigarette use was based on the question "On average over your lifetime, out of every 100 } \\
\text { cigarettes you smoked, how many were menthol?" }\end{array}$ \\
Slone Epidemiology Center study & $\begin{array}{l}\text { Subjects were asked about the most recent brand and the brand used for the longest period of time to } \\
\text { determine the brand name and whether it was mentholated or not. The consistency of the brand name and }\end{array}$ \\
[53] & $\begin{array}{l}\text { menthol status was not checked. In some analyses, cigarettes smoked prior to 1956 were assumed not to be } \\
\text { mentholated. }\end{array}$ \\
Second American Health & $\begin{array}{l}\text { Details are not given in the methods, but the variable analyzed related to whether current smokers preferred } \\
\text { mentholated cigarettes. }\end{array}$ \\
Foundation study [83] & $\begin{array}{l}\text { Subjects were asked about their smoking history including brand names, with exposure to mentholated } \\
\text { cigarettes derived from the brand names blinded for case-control studies. }\end{array}$ \\
German study [84] & $\begin{array}{l}\text { At baseline subjects were asked "Do you now smoke cigarettes?" followed by "What type of cigarettes are } \\
\text { they? Are they plain or menthol?" Similar questions were asked at annual follow-ups but the answers were not } \\
\text { used in the analyses related to risk of lung cancer. } \\
\text { Smokers were asked to report their use of mentholated cigarettes, with ever use the endpoint used for } \\
\text { analysis. }\end{array}$ \\
\hline Houston study [85]
\end{tabular}

cigarette use (though partially controlled by adjustment for race), and none adjusted for diet.

Generally, the papers did not present results that allowed the reader to determine the effect adjustments for individual variables had on the relative risk estimates. Also, no paper discusses the appropriateness or otherwise of adjusting for smoking characteristics, such as amount smoked or inhalation which may be affected by the choice of brand smoked. There are two conflicting issues here. One is wishing to guard against any potential bias arising if the sort of person who chooses mentholated cigarettes is a more (or less) "addicted" smoker than the sort of person who chooses non-mentholated cigarettes. The other is that if, say, switching to mentholated cigarettes results in an increase in daily consumption with no change in risk per cigarette, adjusting for amount smoked will lead to the impression that mentholation is risk free when it is not. Ideally, the comparison should be between switchers to mentholated cigarettes and nonswitchers, adjusted for smoking characteristics before the switch, but such analyses seem never to have been attempted.

\section{Statistical methods used}

Generally, the statistical methods used were standard, with Cox proportion hazards modelling used for the two prospective studies [51,56], and unconditional logistic regression used for all the case-control studies, except the German study [84] which used conditional logistic regression analysis. Four of the case-control studies which used a matched design $[68,69,83,85]$ used unconditional logistic regression, so did not specifically take the matching into account. This was no doubt to avoid loss of power, as some case-control pairs where one subject had never smoked (or in some studies been a former smoker) would not have contributed to a conditional analysis. However, the studies generally took into account most of the matching variables as adjustment variables in analysis. Exceptions were hospital and date of interview in the two American Health Foundation studies [68,83].

\section{Results by histological type}

Only one study, the first reported [68], gave results by histological type. This is a limitation of the available data.

\section{NOS study quality score}

Of the two cohort studies, the Kaiser Permanente Study [51] scored 9 out of a possible 9, while the Lung Health Study [56] scored 8, the only weakness being the unrepresentativeness of the cohort, with mild or moderate airways obstruction. All of the six case-control studies scored between 5 and 7 , the commonest weaknesses being lack of blind ascertainment of exposure in all six studies, failure to demonstrate that lung cancer cases had been excluded from the controls in four studies, use of hospital controls in three studies, and differing response rates (or lack of information on response rates) in three studies. Wells et al [81] do not specify a particular cut-off value for "good quality" studies, and in the meta-analyses following results are compared between those three studies with scores of 7 to 9 and the other five studies with scores of 5 to 6 . Fuller details of the study quality scoring are available in additional file 2 : Study quality. 


\section{Meta-analysis of results for use of mentholated cigarettes Use of mentholated cigarettes}

Table 17 summarizes available RRs and CIs for use of mentholated cigarettes from the eight studies by gender, race and overall. As is evident, the definition of use varies between study, with five studies [53,68,69,84,85] comparing ever and never users of mentholated cigarettes, and three $[51,56,83]$ using alternative comparisons, based on the current or usual brand smoked. The RRs are adjusted for age, gender (where relevant), race (where relevant), smoking habits and other variables. Where the source provides multiple adjusted RRs, those adjusted for the most variables are presented in Table 17. The only individual RRs in the table that are statistically significant at $\mathrm{p}$ $<0.05$ are the increased risk (RR 1.45, CI 1.03-2.02) in males observed in the Kaiser Permanente study [51], and the decreased risks observed in the Second American Health Foundation study [83] in females $(0.66,0.46-0.95)$ and in White people $(0.76,0.60-0.96)$.

Table 18 gives the results of various meta-analyses. None show significant $(\mathrm{p}<0.05)$ heterogeneity between estimates, and, although random-effects estimates are referred to in the text below, fixed-effect and randomeffects estimates are practically the same.

Based on the overall result from each study, and preferring results for ever smokers to results for current smokers where there is a choice (in the Houston study [85]), the meta-analysis estimate (RR 0.93, CI 0.84-1.02) shows no excess lung cancer risk for mentholated over non-mentholated cigarettes (see also Figure 2). This is also true for estimates subdivided by study design, NOS study quality score, study size or year of publication, or when results from the first two hospital case-control studies $[53,68]$ were excluded to avoid possible doublecounting of some cases. Five of the studies $[51,53,68,69,83]$ gave gender-specific results with the meta-analysis estimate not significantly increased in males (1.01, 0.84-1.22), despite the significant increase seen in the Kaiser Permanente study [51], and significantly decreased in females $(0.80,0.67-0.95)$. Three of the studies $[53,69,83]$ gave results separately by race, with one study conducted in White people [84] and one in Black people [85]. The meta-analyses show no evidence of an effect of mentholation in either White $(0.87$, $0.75-1.03)$ or Black $(0.90,0.73-1.10)$ people. Replacing the ever smoker estimate from the Houston study [85] by that for current smokers made little difference to the overall estimate (which became 0.92 (0.84-1.02)), or that for Black people (which became $0.88(0.70-1.10)$ ). Nor is there any evidence of an effect overall in ever smokers specifically $(0.91,0.78-1.07)$ or in current smokers specifically $(0.91,0.81-1.03)$. Only one study provided an estimate for former smokers and that $(0.99,0.62-1.56)$ also showed no effect.
Only one study [68] gave estimates by lung cancer type, but, as shown in Table 4, there was no evidence of an effect of mentholation for any of the four lung cancer types studied.

Only one study [51] gave estimates by age group. As shown in Table 5, there was no indication of heterogeneity by age, the (gender-specific) RRs for the four age groups being consistent with those for the combined age groups.

Only one study [83] provided estimates jointly by race and gender, but, as shown in Table 12, none of these were statistically significant.

Three of the studies $[53,69,83]$ presented comparable RR estimates that were similarly adjusted for non-smoking variables but were either adjusted or not adjusted for smoking. In the Los Angeles County study [69], adjustment for smoking habits increased the overall RR from $0.87(0.66-1.15)$ to $1.00(0.72-1.40)$, in the Slone Epidemiology Center study [53], adjustment increased it from $0.70(0.57-0.88)$ to 0.89 (0.69-1.14), and in the Second American Health Foundation study [83], adjustment increased from $0.66(0.56-0.79)$ to 0.83 (0.68-1.02). As discussed earlier, the extent to which adjustment for smoking habits should be carried out is open to question. However, these results do not suggest that the failure to find an increased risk from mentholated cigarettes depends crucially on smoking adjustment.

For the principal meta-analysis, for which the data are shown in Figure 2, there was no indication of publication bias, as assessed by Egger's test[82] or by a funnel plot (Figure 3).

\section{Meta-analysis of results for long-term use of mentholated cigarettes}

Table 19 summarizes available RRs and CIs for long term use of mentholated cigarettes from the four studies providing relevant data. The definitions of long term use vary by study, two studies giving results for $15+$ years use, one for $20+$ years use, and one for $32+$ pack-years of use. As for Table 17, the RRs are always the mostadjusted available. None of the individual RRs shown in Table 19 are statistically significant.

Table 20 gives the results of meta-analysis overall and by gender and race. None of the random-effects estimates suggest any effect of long term mentholation use on risk of lung cancer, either overall (RR 0.95, CI 0.801.13 - see also Figure 4 - or for males (1.13, 0.86-1.47), females $(0.78,0.60-1.01)$, White $(1.02,0.71-1.46)$ or Black (0.96, 0.71-1.30) people. However, there are few estimates, four for the overall results and those by gender, and only two for the results by race. No significant heterogeneity was evident in any of the analyses.

Some of these studies also report other results by extent of use of mentholated cigarettes. In the Los 
Table 17 Risk of lung cancer by use of mentholated cigarettes ${ }^{a}$ (adjusted for age, gender, race, smoking habits and other variables ${ }^{\text {}}$ )

\begin{tabular}{|c|c|c|c|c|c|c|}
\hline \multirow[b]{2}{*}{ Study } & \multirow[b]{2}{*}{ Comparison } & \multicolumn{5}{|l|}{$\mathrm{RR}(\mathrm{Cl})$} \\
\hline & & Males & Females & White people & Black people & Overall total \\
\hline $\begin{array}{l}\text { American Health } \\
\text { Foundation } 1[68]\end{array}$ & $\begin{array}{l}\text { Ever/never used M (in current } \\
\text { smokers) }\end{array}$ & $1.06(0.82-1.37)$ & $0.78(0.57-1.08)$ & & & $0.94(0.77-1.15)$ \\
\hline Kaiser Permanente [51] & $\begin{array}{l}\text { Usual brand } \mathrm{M} \text { or not (in current } \\
\text { smokers for } 20+\text { years) }\end{array}$ & $1.45(1.03-2.02)$ & $0.75(0.51-1.11)$ & & & $1.09(0.85-1.41)$ \\
\hline Los Angeles [69] & $\begin{array}{l}\text { Ever/never used M (in ever } \\
\text { smokers) }\end{array}$ & $1.00(0.68-1.48)$ & $0.88(0.50-1.57)$ & $1.02(0.66-1.58)$ & $0.89(0.53-1.47)$ & $1.00(0.72-1.40)$ \\
\hline $\begin{array}{l}\text { Slone Epidemiology } \\
\text { Center study [53] }\end{array}$ & $\begin{array}{l}\text { Ever/never used M (in ever } \\
\text { smokers) }\end{array}$ & $0.77(0.55-1.08)$ & $1.05(0.72-1.55)$ & $0.93(0.69-1.24)$ & $0.91(0.52-1.59)$ & $0.89(0.69-1.14)$ \\
\hline $\begin{array}{l}\text { American Health } \\
\text { Foundation } 2 \text { [83] }\end{array}$ & $\begin{array}{l}\text { Currently prefers/does not prefer M } \\
\text { (in current smokers) }\end{array}$ & $0.92(0.72-1.17)$ & $0.66(0.46-0.95)$ & $0.76(0.60-0.96)$ & $1.09(0.72-1.65)$ & $0.83(0.68-1.02)$ \\
\hline German [84] & $\begin{array}{l}\text { Ever/never used M (in ever } \\
\text { smokers) }\end{array}$ & & & $1.12(0.68-1.83)^{\mathrm{C}}$ & & $1.12(0.68-1.83)$ \\
\hline Lung Health [56] & $\begin{array}{l}\text { Current brand } \mathrm{M} \text { or not (in current } \\
\text { smokers) }\end{array}$ & & & & & $0.96(0.70-1.32)$ \\
\hline \multirow[t]{3}{*}{ Houston [85] } & $\begin{array}{l}\text { Ever/never used M (in ever } \\
\text { smokers) }\end{array}$ & & & & $0.81(0.60-1.09)^{c}$ & $0.81(0.60-1.09)$ \\
\hline & (in current smokers) & & & & $0.69(0.46-1.03)^{c}$ & $0.69(0.46-1.03)$ \\
\hline & (in former smokers) & & & & $0.99(0.62-1.56)^{c}$ & $0.99(0.62-1.56)$ \\
\hline
\end{tabular}

\footnotetext{
${ }^{a}$ Mentholated cigarettes abbreviated to $\mathrm{M}$ in the table.
}

${ }^{b}$ All estimates are adjusted for age, gender and race except for those that are gender-specific or race-specific. All estimates are adjusted for smoking habits except for the current and former smoker estimates from the Houston study. See Table 14 for fuller details of adjustment variables.

c Same as the overall results, as the studies were only of White people [84] or Black people [85].

Angeles County Study [69], no excess risk was seen comparing ever smokers with $75-100 \%$ mentholated cigarette use with those with $0 \%$ use $(1.02,0.65-1.63)$ or comparing those with exclusive mentholated cigarette use with exclusive regular cigarette use (1.04, 0.62-1.75). Nor were significant effects of mentholation seen when the 32+ pack-years category was subdivided into 32-53 and $54+$ pack years, RRs based on limited data being $0.76(0.37-1.59)$ and 1.38 (0.56-3.40). In the Slone Epidemiology Center study [53], ever smokers with $50 \%$ or more mentholated cigarette use had no excess risk compared to those with no use $(0.89,0.65-1.22)$. That study also presented estimates of risk for $>15$ years use of mentholated cigarettes alternative to that of 0.89 (0.691.14) used in Tables 19 and 20. As shown in Table 11, no association was seen with lung cancer risk whether different subsets of smokers were used or whether different assumptions were made concerning data on brand history.

\section{Can mentholation explain the higher lung cancer risk in US Black people?}

It is often suggested, e.g. [17,67-69], that the greater preference of Black people for mentholated cigarettes might help to explain the higher lung cancer rates seen in Black males compared to White males. However, the epidemiological findings would appear to argue otherwise. For mentholation to be the major cause one would expect to see a substantially higher risk of lung cancer in mentholated cigarette smokers, but this is not the case. Table 21 presents approximate calculations suggesting that explaining the $36 \%$ increase in incidence and $31 \%$ increase in mortality reported in Black males compared to White males [66] requires the relative risk of lung cancer associated with mentholation to be about 1.7 or 1.8. In fact, as shown in Table 18, the relative risk for mentholation estimated from the combined available evidence is 0.93 , with an upper $95 \%$ confidence limit of only 1.02 , far less than 1.7 or 1.8. Even for long term use (see Table 20) the estimate of 0.95 has an upper $95 \%$ confidence limit of only 1.13 . Though a small contribution of mentholation to the excess risk in US Black people cannot be ruled out, a major contribution seems totally implausible based on the available data. The fact that Black females, compared to White females, are much more likely to use mentholated cigarettes but have quite similar lung cancer mortality, strengthens this view.

\section{Discussion}

As noted earlier, there has been increasing regulatory interest in the possible contribution of additives to the carcinogenicity of cigarettes, both in the United States and Europe. In principle, menthol is by far the easiest to study, as brand names clearly identify whether or not the cigarette is mentholated, and smokers will be well aware anyway whether the cigarettes they are smoking are mentholated. Also mentholated cigarettes 


\begin{tabular}{|c|c|c|c|c|}
\hline & \multirow{2}{*}{$\begin{array}{l}\text { Number of } \\
\text { Estimates }\end{array}$} & \multicolumn{2}{|l|}{ RR $(95 \% \mathrm{Cl})$} & \multirow[t]{2}{*}{ Heterogeneity $\chi^{2}(\mathrm{df}), \mathrm{p}$} \\
\hline & & Fixed-effect & Random-effects & \\
\hline \multicolumn{5}{|c|}{ In ever smokers (or current smokers if not available) } \\
\hline Overall & 8 & $0.93(0.84-1.02)$ & $0.93(0.84-1.02)$ & $4.43(7), 0.73$ \\
\hline \multicolumn{5}{|l|}{ Study design } \\
\hline - prospective & 2 & $1.04(0.85-1.26)$ & $1.04(0.85-1.26)$ & $0.38(1), 0.54$ \\
\hline - hospital case-control & 3 & $0.89(0.78-1.00)$ & $0.89(0.78-1.00)$ & $0.73(2), 0.69$ \\
\hline - population case-control & 3 & $0.92(0.76-1.13)$ & $0.92(0.76-1.13)$ & $1.54(2), 0.46$ \\
\hline \multicolumn{5}{|l|}{ NOS study quality score } \\
\hline-7 to 9 & 3 & $1.03(0.87-1.22)$ & $1.03(0.87-1.22)$ & $0.41(2), 0.84$ \\
\hline-5 to 6 & 5 & $0.88(0.79-0.99)$ & $0.88(0.79-0.99)$ & $1.94(4), 0.75$ \\
\hline \multicolumn{5}{|l|}{ Study size } \\
\hline$-<125$ cases $^{\mathrm{a}}$ & 4 & $0.99(0.85-1.15)$ & $0.99(0.85-1.15)$ & $1.52(3), 0.68$ \\
\hline - 125+ cases & 4 & $0.89(0.79-1.00)$ & $0.89(0.79-1.00)$ & $1.59(3), 0.66$ \\
\hline \multicolumn{5}{|l|}{ Year of publication } \\
\hline - 1991 to 2000 & 3 & $1.00(0.86-1.15)$ & $1.00(0.86-1.15)$ & $0.81(2), 0.67$ \\
\hline - 2001 to 2008 & 5 & $0.88(0.77-0.99)$ & $0.88(0.77-0.99)$ & $1.82(4), 0.77$ \\
\hline Avoiding possible overlap ${ }^{b}$ & 6 & $0.93(0.83-1.04)$ & $0.93(0.83-1.04)$ & $4.31(5), 0.51$ \\
\hline Males & 5 & $1.01(0.88-1.15)$ & $1.01(0.84-1.22)$ & $7.62(4), 0.11$ \\
\hline Females & 5 & $0.80(0.67-0.95)$ & $0.80(0.67-0.95)$ & $3.25(4), 0.52$ \\
\hline White people & 4 & $0.87(0.75-1.03)$ & $0.87(0.75-1.03)$ & $2.98(3), 0.40$ \\
\hline Black people & 4 & $0.90(0.73-1.10)$ & $0.90(0.73-1.10)$ & $1.30(3), 0.73$ \\
\hline \multicolumn{5}{|c|}{ In current smokers (or ever smokers if not available) } \\
\hline Overall & 8 & $0.92(0.84-1.02)$ & $0.92(0.84-1.02)$ & $5.70(7), 0.58$ \\
\hline Black people & 4 & $0.88(0.70-1.10)$ & $0.88(0.70-1.10)$ & $2.44(3), 0.49$ \\
\hline \multicolumn{5}{|l|}{ In ever smokers specifically } \\
\hline Overall & 4 & $0.91(0.78-1.07)$ & $0.91(0.78-1.07)$ & $1.60(3), 0.66$ \\
\hline \multicolumn{5}{|c|}{ In current smokers specifically } \\
\hline Overall & 5 & $0.91(0.82-1.02)$ & $0.91(0.81-1.03)$ & $4.76(4), 0.31$ \\
\hline \multicolumn{5}{|c|}{ In former smokers specifically } \\
\hline Total & 1 & $0.99(0.62-1.56)$ & $0.99(0.62-1.56)$ & - \\
\hline
\end{tabular}

${ }^{a}$ Lung cancer cases in mentholated cigarette smokers.

${ }^{\mathrm{b}}$ Excluding first American Health Foundation Study and Slone Epidemiology Center study.

are quite widely smoked, particularly in the United States, especially in Black people who have a much greater preference for them than do White people (see Table 1).

While menthol itself has been widely used for many years and experimental studies provide no reason for concern that it is genotoxic or carcinogenic $[7,8]$, there is a suggestion that its acute effects on the mouth, nose and respiratory system [6] may affect how smoke from cigarettes is inhaled [10]. Coupled with evidence in the United States that Black males have markedly higher lung cancer rates than do White males (see Table 2), despite Black people smoking less heavily and tending to start smoking later in life than do White people (see e.g. Table 3), it is often suggested (e.g. [17,67-69]) that mentholation of cigarettes may increase the risk of lung cancer.
The main objective of this paper is to investigate this possibility by a direct epidemiological comparison of risk in mentholated and non-mentholated cigarette smokers. However, it should be noted that various other pieces of evidence argue against this possibility. First, data from a number of studies (see e.g. $[9,45]$ ) provide no convincing evidence that mentholation increases puffing, inhalation or tobacco smoke uptake. Also, Black females have similar lung cancer rates (see Table 2) to White females, despite the preference for mentholated cigarettes in Black people being at least as great in females as in males (see Table 1). It should also be noted that, as described in the Background section, there are other differences in smoking characteristics between Black and White people, with Black people being more likely to be current smokers, less likely to quit, tending to choose higher tar cigarettes and having 


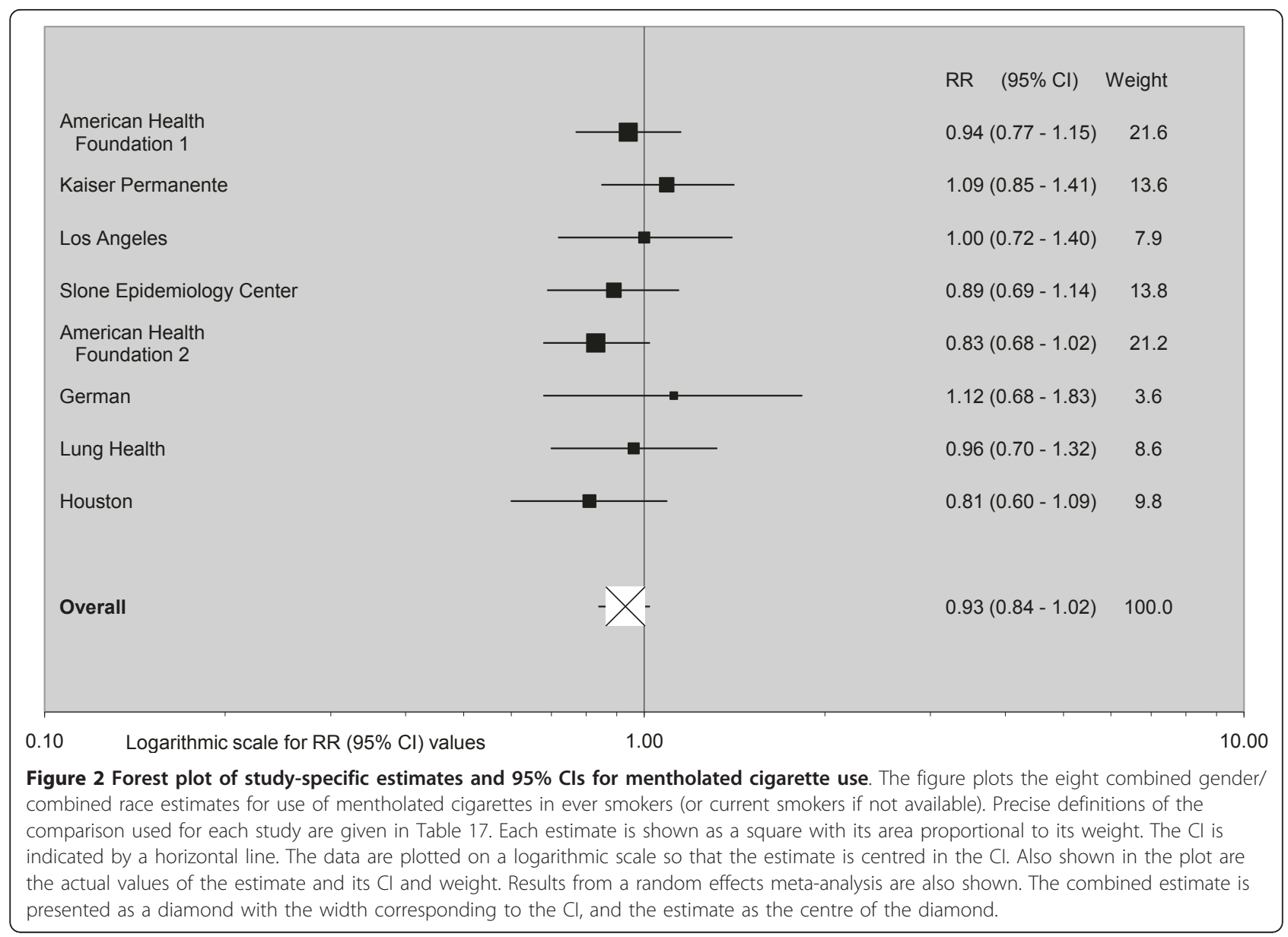

higher cotinine levels. Other differences between Black and White people may also be relevant, for example in body mass index, access to health care and metabolism.

Although mentholated cigarettes have assumed an important place in the United States cigarette market over the last 50 years, and the number of published epidemiological studies of smoking and lung cancer is extremely large, relatively few publications provide information comparing risk in smokers according to use of mentholated cigarettes.

While only eight relevant studies were identified, and two of the papers reporting on this relationship $[83,85]$ did not have mentholation as a central interest and one [84] was published only as an abstract, the data available to study effects of mentholation seem quite good. The studies are reasonably large, involving in total some 1200 lung cancers in mentholated cigarette smokers and are of standard designs analysed by standard methods. Cases are generally histopathologically confirmed, with selection of controls unlikely to cause relevant bias. All the studies take age, gender, race and other aspects of smoking into account in their analyses, with some adjustment for other potential confounding variables such as education and body mass index.

Nevertheless, the studies have limitations. These include failure to present results by histological type (except in one study [68]), failure to adjust for occupation or diet, and failure to report results by length of use of mentholated cigarettes in the later published studies [56,83-85] - important as the earlier studies $[51,53,68,69]$ had insufficient subjects who smoked mentholated cigarettes for a long time. One would like to be able to compare subjects who smoked only mentholated or only non-mentholated cigarettes for 30 years or more.

Another issue is the extent and reliability of the data on lifetime use of mentholated cigarettes. Some studies only collected or analyzed information on brand currently smoked $[51,56,83]$ or on a few brands smoked during lifetime [53], and some studies collecting data on names of brands smoked and whether the brand was mentholated $[51,53]$ seemed not to cross-check this information. The reliability of statements on brands smoked years ago is in any case questionable [89]. 


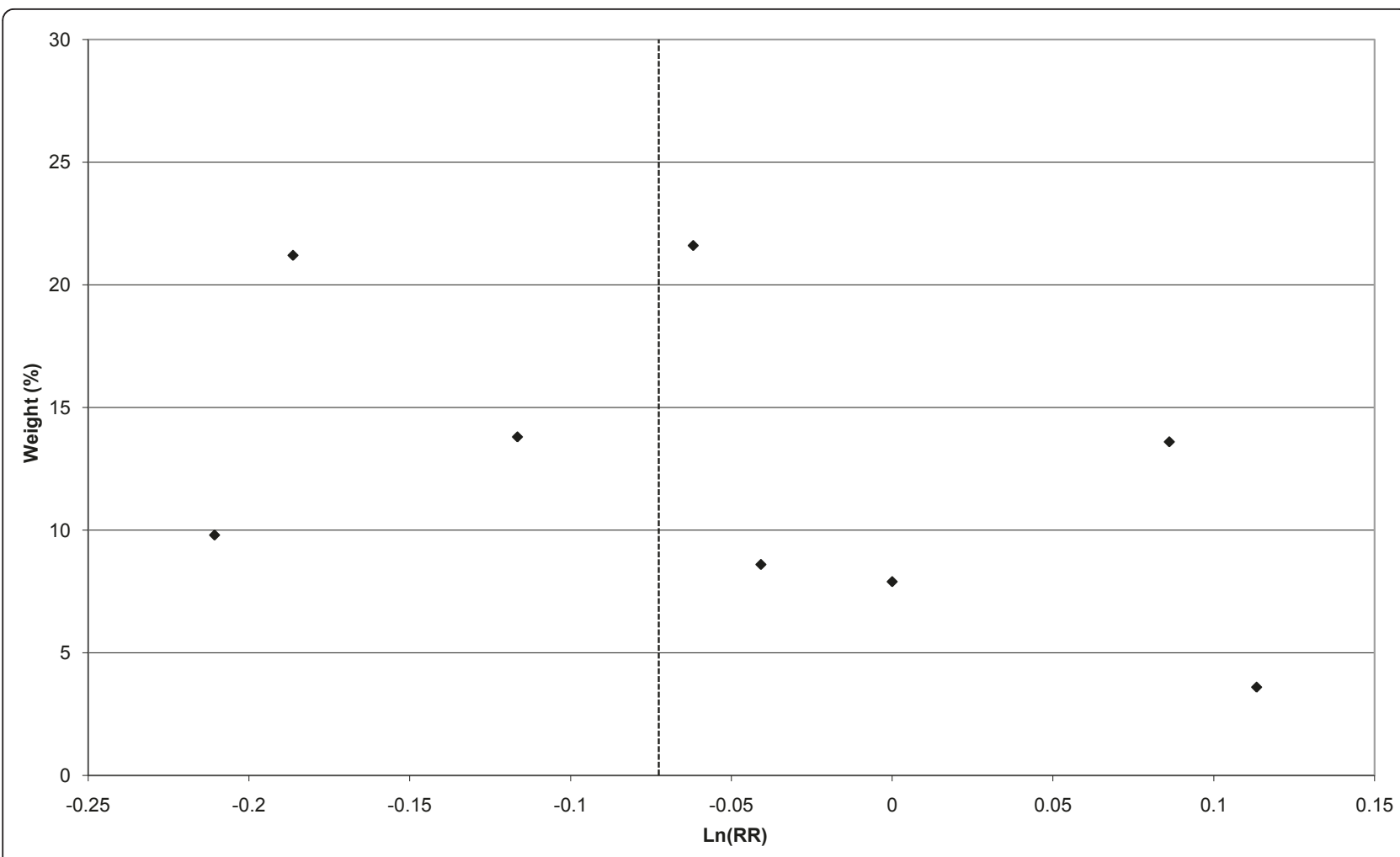

Figure 3 Funnel plot for risk of lung cancer by use of mentholated cigarettes. Funnel plot of the eight relative risk estimates for use of mentholated cigarettes and lung cancer shown in Figure 2 against their weight (inverse-variance of log RR.) The dotted vertical line indicates the fixed-effect meta-analysis estimate.

Table 19 Risk of lung cancer by long-term use of mentholated cigarettes ${ }^{a}$ (adjusted for age, gender, race, smoking habits and other variables ${ }^{\text {b }}$ )

\begin{tabular}{|c|c|c|c|c|c|c|}
\hline \multirow[b]{2}{*}{ Study } & \multirow[b]{2}{*}{ Exposure $^{c}$} & \multicolumn{5}{|l|}{$\mathrm{RR}(\mathrm{Cl})$} \\
\hline & & Males & Females & $\begin{array}{l}\text { White } \\
\text { people }\end{array}$ & $\begin{array}{l}\text { Black } \\
\text { people }\end{array}$ & Total \\
\hline $\begin{array}{l}\text { American Health Foundation } 1 \\
\text { [68] }\end{array}$ & $15+$ years use of $M$ (in current smokers) & $\begin{array}{l}0.98(0.70- \\
1.38)\end{array}$ & $\begin{array}{l}0.76(0.53- \\
1.16)\end{array}$ & & & $\begin{array}{l}0.88(0.68- \\
1.14)\end{array}$ \\
\hline Kaiser Permanente [51] & $\begin{array}{l}20+\text { years use of } M \text { (in current smokers for } \\
20+\text { years) }\end{array}$ & $\begin{array}{l}1.59(0.96- \\
2.63)\end{array}$ & $\begin{array}{l}0.70(0.40- \\
1.23)\end{array}$ & & & $\begin{array}{l}1.10(0.76- \\
1.60)\end{array}$ \\
\hline Los Angeles [69] & 32+ pack-years M (in ever smokers) & $\begin{array}{l}1.48(0.71- \\
3.05)\end{array}$ & $\begin{array}{l}0.41(0.15- \\
1.11)\end{array}$ & $\begin{array}{l}1.06(0.47- \\
2.36)\end{array}$ & $\begin{array}{l}0.90(0.38- \\
2.12)\end{array}$ & $\begin{array}{l}0.95(0.53- \\
1.70)\end{array}$ \\
\hline $\begin{array}{l}\text { Slone Epidemiology Center } \\
\text { study [53] }\end{array}$ & $15+$ years of $M$ (in ever smokers) & $\begin{array}{l}0.91(0.57- \\
1.46)\end{array}$ & $\begin{array}{l}1.00(0.63- \\
1.60)\end{array}$ & $\begin{array}{l}1.01(0.68- \\
1.51)\end{array}$ & $\begin{array}{l}1.21(0.64- \\
2.26)\end{array}$ & $\begin{array}{l}0.97(0.70- \\
1.34)\end{array}$ \\
\hline
\end{tabular}

${ }^{a}$ Mentholated cigarettes abbreviated to $\mathrm{M}$ in the table; reference group is those with no use of mentholated cigarettes.

${ }^{\mathrm{b}}$ Details of all adjustment variables are given in Table 14.

Table 20 Meta-analyses of risk of lung cancer by long term use of mentholated cigarettes

\begin{tabular}{|c|c|c|c|c|}
\hline & \multirow[t]{2}{*}{ Number of Estimates } & \multicolumn{2}{|l|}{ RR (95\% Cl) } & \multirow[t]{2}{*}{ Heterogeneity $\chi^{2}(\mathrm{df}), \mathrm{p}$} \\
\hline & & Fixed-effect & Random-effects & \\
\hline Overall & 4 & $0.95(0.80-1.13)$ & $0.95(0.80-1.13)$ & $0.95(3), 0.81$ \\
\hline Males & 4 & $1.11(0.88-1.39)$ & $1.13(0.86-1.47)$ & $3.76(3), 0.29$ \\
\hline Females & 4 & $0.78(0.60-1.01)$ & $0.78(0.60-1.01)$ & $2.84(3), 0.42$ \\
\hline White people & 2 & $1.02(0.71-1.46)$ & $1.02(0.71-1.46)$ & $0.01(1), 0.92$ \\
\hline Black people & 2 & $1.09(0.66-1.81)$ & $1.09(0.66-1.81)$ & $0.30(1), 0.59$ \\
\hline
\end{tabular}




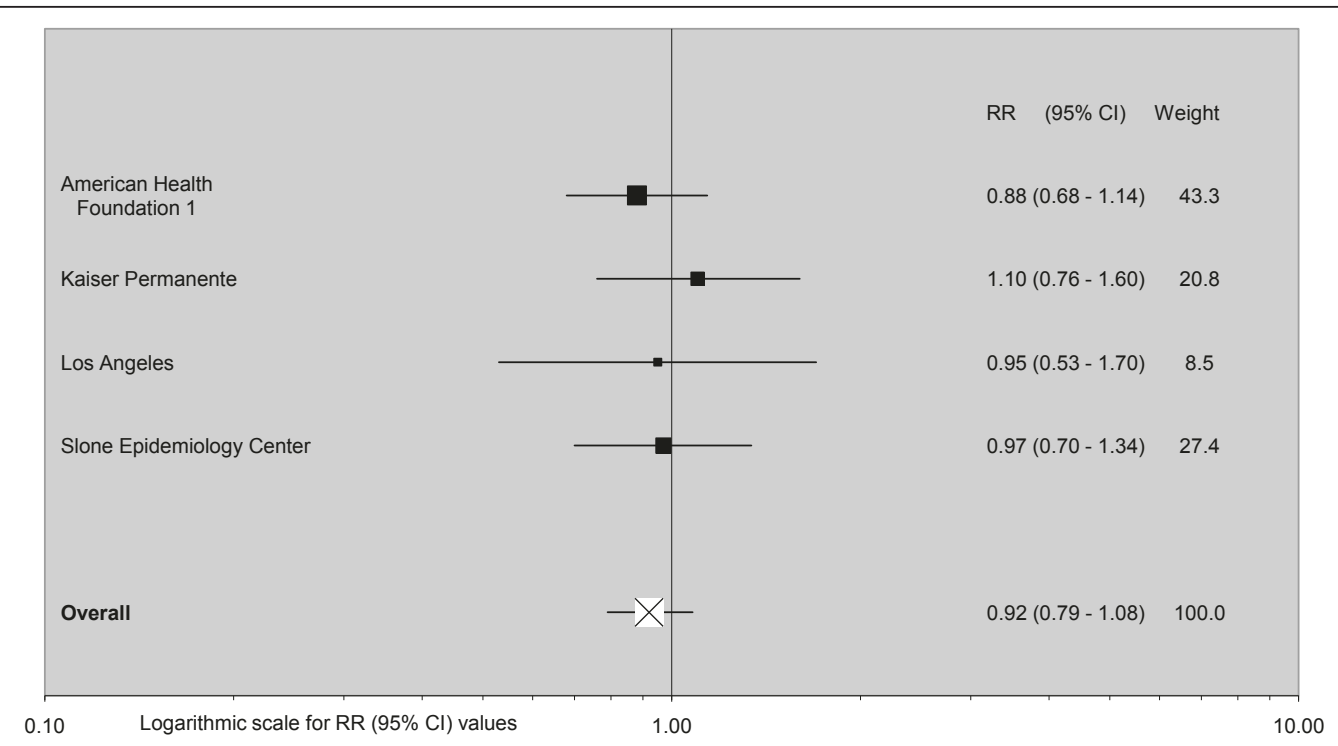

Figure 4 Forest plot of study-specific estimates and $\mathbf{9 5 \%} \mathrm{Cls}$ for long-term use of mentholated cigarettes. The figure plots the four combined gender/combined race estimates for long-term use of mentholated cigarettes in ever smokers (or current smokers if not available). Precise definitions of the comparison used for each study are given in Table 19. Each estimate is shown as a square with its area proportional to its weight. The $\mathrm{Cl}$ is indicated by a horizontal line. The data are plotted on a logarithmic scale so that the estimate is centred in the $\mathrm{Cl}$. Also shown in the plot are the actual values of the estimate and its $\mathrm{Cl}$ and weight. Results from a random effects meta-analysis are also shown. The combined estimate is presented as a diamond with the width corresponding to the $\mathrm{Cl}$, and the estimate as the centre of the diamond.

Table 21 Approximate estimation of the relationship in males between the mentholated/non-mentholated lung cancer relative risk (RR) and the estimated lung cancer risk of Black people relative to White people

\begin{tabular}{|c|c|c|c|c|c|c|c|c|c|}
\hline & & \multirow{2}{*}{$\begin{array}{l}\text { Never smoked } \\
\text { Total }\end{array}$} & \multicolumn{3}{|c|}{ Ex smoker } & \multicolumn{3}{|c|}{ Current smoker } & \multirow{2}{*}{$\begin{array}{l}\text { Total } \\
\text { Total }\end{array}$} \\
\hline & & & Total & Menthol & Non-menthol & Total & Menthol & Non-menthol & \\
\hline & & (1) & & $(2)$ & (3) & & (4) & (5) & \\
\hline & \multicolumn{9}{|l|}{ White people } \\
\hline & $\overline{\text { Frequency }^{1}}$ & 0.501 & 0.262 & & & 0.237 & & & 1.000 \\
\hline & Menthol proportion ${ }^{b}$ & & & 0.218 & 0.782 & & 0.218 & 0.782 & \\
\hline (a) & Frequency by menthol & 0.501 & & 0.057 & 0.205 & & 0.052 & 0.185 & 1.000 \\
\hline \multirow[t]{4}{*}{ (b) } & Risk relative to never smokers ${ }^{c}$ & 1.00 & 9.36 & 9.36RR & 9.36 & 22.36 & $22.36 \mathrm{RR}$ & 22.36 & \\
\hline & Black people & & & & & & & & \\
\hline & $\overline{\text { Frequency }^{1}}$ & 0.572 & 0.158 & & & 0.270 & & & 1.000 \\
\hline & Menthol proportion ${ }^{b}$ & & & 0.835 & 0.165 & & 0.835 & 0.165 & \\
\hline (a) & Frequency by menthol & 0.572 & & 0.132 & 0.026 & & 0.225 & 0.045 & 1.000 \\
\hline \multirow[t]{9}{*}{ (b) } & Risk relative to never smokers ${ }^{c}$ & 1.00 & 9.36 & $9.36 R R$ & 9.36 & 22.36 & $22.36 R R$ & 22.36 & \\
\hline & Assumed value of $\mathrm{RR}$ & & & & Black White rela & ive risk $^{d}$ & & & \\
\hline & 1.0 & & & & 0.980 & & & & \\
\hline & 1.1 & & & & 1.035 & & & & \\
\hline & 1.2 & & & & 1.088 & & & & \\
\hline & 1.3 & & & & 1.138 & & & & \\
\hline & 1.5 & & & & 1.234 & & & & \\
\hline & 1.8 & & & & 1.365 & & & & \\
\hline & 2.0 & & & & 1.445 & & & & \\
\hline
\end{tabular}

a See Table 3.

b See Table 1 - proportions assumed the same for current and ex smokers.

c The source of the relative risk estimates of 9.36 for ex smokers and 22.36 for current smokers is the 1989 US Surgeon-General's Report Table 6 p150 [65]. As they are based on Cancer Prevention Study II starting in 1982, a study in a predominantly White population, the relative risk estimates have been assumed to apply to non-mentholated cigarette smokers. RR is the assumed relative risk for mentholated compared to non-mentholated cigarette smoking.

' Estimated by summing for each race, the product of rows (a) and (b) over columns (1), (2), (3), (4) and (5), and then dividing the total for Black people by the total for White people. 
The analyses presented are typically adjusted for smoking habits, such as daily cigarette consumption and duration of smoking. This is an attempt to compare mentholated and non-mentholated cigarette smokers with an equivalent smoking history. None of the analyses have attempted to account for the possibility that switching from non-mentholated to mentholated cigarettes might be associated with changes in cigarette consumption.

The combined data from the eight studies are not at all suggestive of any effect of mentholation on lung cancer risk. Meta-analysis of adjusted RRs for ever use give a combined estimate of 0.93 (95\% CI 0.84-1.02), with individual estimates showing remarkably little heterogeneity, varying only from 0.81 to 1.12 . The same is true for longterm use, where the combined estimate of 0.95 (0.80-1.13) is again based on consistent individual estimates, varying from 0.88 to 1.10 . There is also no evidence of an increase in males or females separately, in Black or White people separately or in estimates for ever smokers, current smokers or former smokers. Limited data on risk by age and by histological type of lung cancer also suggest no effect of mentholation. There is a question as to the validity of adjustment for aspects of smoking habits that might be affected by use of mentholated cigarettes, but the estimates that are adjusted only for non-smoking variables tend to be lower. Overall the data, taken as a whole, could hardly be more indicative of a lack of relationship.

For mentholation to explain the increased lung cancer risk in Black compared to White males of some 30-35\% would require a relative risk of about 1.7 to 1.8 . The excess risk, therefore, cannot possibly be explained by the much greater preference of Black people for mentholated cigarettes.

\section{Conclusion}

While there are some weaknesses in the studies presenting data, discussed in detail in the report, the evidence taken as a whole is certainly consistent with the addition of menthol to tobacco having no effect on the lung carcinogenicity of cigarettes. The much greater preference for mentholated cigarettes in Black people in the United States cannot possibly explain their higher lung cancer risk, which in any case in evident only in men.

\section{Additional material}

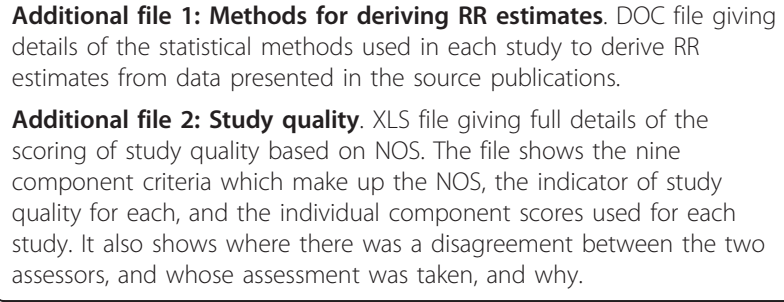

\section{Abbreviations}

$\mathrm{Cl}$ : confidence interval; CO: carbon monoxide; NOS: Newcastle-Ottawa quality assessment scale; RR: relative risk; SCENIHR: Scientific Committee on Emerging and Newly-Identified Health Risks; TPSAC: Tobacco Products Scientific Advisory Committee (TPSAC)

\section{Acknowledgements}

This research was funded by the Lorillard Tobacco Company. However, the opinions and conclusions of the author are his own and do not necessarily reflect the position of Lorillard. I thank Mary Lane for assistance in the literature search, Yvonne Cooper for help in obtaining the relevant literature, and Pauline Wassell and Diane Morris for typing the various drafts of the paper. I also thank Dr John Fry for carrying out the checks described in the methods section, and for other helpful comments on drafts of the text, Jan Hamling for assistance in conducting the meta-analyses and preparing the forest plots, and Katharine Coombs for assessment of study quality. Finally, I thank the reviewers for their valuable comments, which have helped to improve the paper.

\section{Authors' contributions}

The author planned the study, and carried out all phases of it, except as indicated in the acknowledgements section.

\section{Competing interests}

The author, founder of P.N. Lee Statistics and Computing Ltd., is an independent consultant in statistics and an adviser in the fields of epidemiology and toxicology to a number of tobacco, pharmaceutical and chemical companies.

Received: 10 September 2010 Accepted: 18 April 2011

Published: 18 April 2011

\section{References}

1. Giovino GA, Sidney S, Gfroerer JC, O'Malley PM, Allen JA, Richter PA, Cummings KM: Epidemiology of menthol cigarette use. Nicotine Tob Res 2004, 6(Suppl 1):S67-S81.

2. Hebert JR, Kabat GC: Menthol cigarettes and esophageal cancer [Letter]. Am J Public Health 1988, 78:986-987.

3. Hebert JR, Kabat GC: Menthol cigarette smoking and oesophageal cancer. Int J Epidemiol 1989, 18:37-44

4. Liberati A, Altman DG, Tetzlaff J, Mulrow C, Gøtzsche PC, loannidis JPA, Clarke M, Devereaux PJ, Kleijnen J, Moher D: The PRISMA statement for reporting systematic reviews and meta-analyses of studies that evaluate healthcare interventions: explanation and elaboration. BMJ 2009, 339: b2700.

5. Gaworski CL, Dozier MM, Gerhart JM, Rajendran N, Brennecke LH, Aranyi C Heck JD: 13-week inhalation toxicity study of menthol cigarette smoke. Food Chem Toxicol 1997, 35:683-692.

6. Eccles R: Menthol and related cooling compounds. J Pharm Pharmacol 1994, 46:618-630.

7. National Cancer Institute: Bioassay of DL-menthol for possible carcinogenicity. National Cancer Institute Carcinogenesis Technical Report Series no 98 (NClCG-TR-98) Bethesda, Maryland, US: National Cancer Institute; 1979, US National Technical Information Service Report no PB-288761.

8. Speijers GJA: Menthol. Safety evaluation of certain food additives 2000, 57-76, [WHO Food Additives Series 42.] ISBN 92-4-166042-2..

9. Heck JD: A review and assessment of menthol employed as a cigarette flavoring ingredient. Food Chem Toxicol 2010, 48:S1-S38.

10. Garten S, Falkner RV: Menthol and tobacco smoking 2001 [http://www. goodhealth.freeservers.com/MethTobaccolntro.html].

11. Schmeltz I, Schlotzhauer WS: Benzo[a]pyrene, phenols and other products from pyrolysis of the cigarette additive (d,I)-menthol. Nature 1968, 219:370-371.

12. National Cancer Institute: Survey of compounds which have been tested for carcinogenic activity - 1978 volume Bethesda, MD: US Department of Health and Human Services. Public Health Service; 1980, NIH Pub No 80-453.

13. National Toxicology Program: Second annual report on carcinogens Bethesda, MD: US Department of Health and Human Services. Public Health Service; 1981. 
14. Newell MP, Latimer PH, Haefle RJ: The fate of menthol in cigarette smoke. 22nd Tobacco Chemists' Research Conference Proceedings 1968, 18.

15. Jenkins RW Jr, Newman RH, Chavis MK: Cigarette smoke formation studies. II. Smoke distribution and mainstream pyrolytic composition of added ${ }^{14} \mathrm{C}$-menthol(U). Beitrage zur Tabakforschung International 1970, 5:299-301.

16. Jenkins RW, Comes RA, Bass RT: The use of carbon-14 labeled compounds in smoke precursor studies: a review. 29th Tobacco Chemists Research Conference 1975.

17. Richardson TL: African-American smokers and cancers of the lung and of the upper respiratory and digestive tracts: is menthol part of the puzzle? West J Med 1997, 166:189-194.

18. Rustemeier K, Stabbert R, Haussmann HJ, Roemer E, Carmines EL: Evaluation of the potential effects of ingredients added to cigarettes. Part 2: Chemical composition of mainstream smoke. Food Chem Toxicol 2002, 40:93-104.

19. Baker RR, Pereira da Silva JR, Smith G: The effect of tobacco ingredients on smoke chemistry. Part I: Flavourings and additives. Food Chem Toxicol 2004, 42S:S3-S37.

20. Ding Y, Trommel J, Yan XJ, Ashley D, Watson C: Determination of 14 polycyclic aromatic hydrocarbons in mainstream smoke from domestic cigarettes. Environ Sci Technol 2005, 39:471-478.

21. Schievelbein $\mathrm{H}$ : Risk to health in smoking menthol cigarettes? Munchener Medizinische Wochenschrift 1969, 111:2457.

22. Gaworski CL, Heck JD, Bennett MB, Wenk ML: Toxicologic evaluation of flavor ingredients added to cigarette tobacco: skin painting bioassay of cigarette smoke condensate in SENCAR mice. Toxicology 1999, 139:1-17.

23. Gaworski CL, Dozier MM, Heck JD, Gerhart JM, Rajendran N, David RM, Brennecke LH, Morrissey R: Toxicologic evaluation of flavor ingredients added to cigarette tobacco: 13-week inhalation exposures in rats. Inhal Toxicol 1998, 10:357-381.

24. Vanscheeuwijck PM, Teredesai A, Terpstra PM, Verbeeck J, Kuhl P, Gerstenberg B, Gebel S, Carmines EL: Evaluation of the potential effects of ingredients added to cigarettes. Part 4: Subchronic inhalation toxicity. Food Chem Toxicol 2002, 40:113-131.

25. Caskey NH, Jarvik ME, McCarthy WJ, Rosenblatt MR, Gross TM, Carpenter CL: Rapid smoking of menthol and nonmenthol cigarettes by black and white smokers. Pharmacol Biochem Behav 1993, 46:259-263.

26. Miller GE, Jarvik ME, Caskey NH, Segerstrom SC, Rosenblatt MR, McCarthy WJ: Cigarette mentholation increases smokers' exhaled carbon monoxide levels. Exp Clin Psychopharmacol 1994, 2:154-160.

27. Ahijevych K, Gillespie J, Demirci M, Jagadeesh J: Menthol and nonmenthol cigarettes and smoke exposure in black and white women. Pharmacol Biochem Behav 1996, 53:355-360.

28. Pickworth WB, Moolchan ET, Berlin I, Murty R: Sensory and physiologic effects of menthol and nonmenthol cigarettes with differing nicotine delivery. Pharmacol Biochem Behav 2002, 71:55-61.

29. Nil R, Bättig K: Separate effects of cigarette smoke yield and smoke taste on smoking behavior. Psychopharmacology 1989, 99:54-59.

30. Jarvik ME, Tashkin DP, Caskey NH, McCarthy WJ, Rosenblatt MR: Mentholated cigarettes decrease puff volume of smoke and increase carbon monoxide absorption. Physiol Behav 1994, 56:563-570.

31. McCarthy WJ, Caskey NH, Jarvik ME, Gross TM, Rosenblatt MR, Carpenter C: Menthol vs nonmenthol cigarettes: effects on smoking behavior. Am J Public Health 1995, 85:67-72.

32. Ahijevych K, Parsley LA: Smoke constituent exposure and stage of change in black and white women cigarette smokers. Addict Behav 1999, 24:115-120.

33. Clark PI, Cautam S, Gerson LW: Effect of menthol cigarettes on biochemical markers of smoke exposure among black and white smokers. Chest 1996, 110:1194-1198.

34. Williams JM, Ghandi KK, Steinberg ML, Foulds J, Ziedonis DM, Benowitz NL: Higher nicotine and carbon monoxide levels in menthol cigarette smokers with and without schizophrenia. Nicotine Tob Res 2007, 9:873-881.

35. Pritchard WS, Houlihan ME, Guy TD, Robinson JH: Little evidence that "denicotinized" menthol cigarettes have pharmacological effects: an EEG/heart-rate/subjectiveresponse study. Psychopharmacology 1999, 143:273-279.

36. Benowitz NL, Herrera B, Jacob PI: Mentholated cigarette smoking inhibits nicotine metabolism. J Pharmacol Exp Ther 2004, 310:1208-1215.
37. Allen B Jr, Unger JB: Sociocultural correlates of menthol cigarette smoking among adult African Americans in Los Angeles. Nicotine and Tobacco Research 2007, 9:447-451.

38. Heck JD: Smokers of menthol and nonmenthol cigarettes exhibit similar levels of biomarkers of smoke exposure. Cancer Epidemiol Biomarkers Prev 2009, 18:622-629, Erratum appears in Cancer Epidemiol. Biomarkers Prev. 2009;18:2155.

39. Wang J, Roethig HJ, Appleton S, Werley M, Mahummad-Kah R, Mendes P: The effect of menthol containing cigarettes on adult smokers' exposure to nicotine and carbon monoxide. Regul Toxicol Pharmacol 2010, 57:24-30.

40. Ahijevych $\mathrm{KL}$, Wewers ME: Patterns of cigarette consumption and cotinine levels among African American women smokers. Am J Respir Crit Care Med 1994, 150:1229-1233.

41. Mustonen TK, Spencer SM, Hoskinson RA Jr, Sachs DPL, Garvey AJ: The influence of gender, race, and menthol content on tobacco exposure measures. Nicotine Tob Res 2005, 7:581-590.

42. O'Connor RJ, Ashare RL, Cummings KM, Hawk LWJr: Comparing smoking behaviors and exposures from flavored and unflavored cigarettes. Addict Behav 2007, 32:869-874.

43. Muscat JE, Chen G, Knipe A, Stellman SD, Lazarus P, Richie JP Jr: Effects of menthol on tobacco smoke exposure, nicotine dependence, and NNAL glucuronidation. Cancer Epidemiol Biomarkers Prev 2009, 18:35-41.

44. Signorello LB, Cai Q, Tarone RE, McLaughlin JK, Blot WJ: Racial differences in serum cotinine levels of smokers. Dis Markers 2009, 27:187-192.

45. Werley MS, Coggins CRE, Lee PN: Possible effects on smokers of cigarette mentholation: A review of the evidence relating to key research questions. Regul Toxicol Pharmacol 2007, 47:189-203.

46. Hyland A, Garten S, Giovino GA, Cummings KM: Mentholated cigarettes and smoking cessation: findings from COMMIT. Tob Control 2002, 11:135-139.

47. Okuyemi KS, Ebersole-Robinson M, Nazir N, Ahluwalia JS: African-American menthol and nonmenthol smokers: differences in smoking and cessation experiences. J Natl Med Assoc 2004, 96:1208-1211.

48. Okuyemi KS, Faseru B, Sanderson Cox L, Bronars CA, Ahluwalia JS: Relationship between menthol cigarettes and smoking cessation among African American light smokers. Addiction 2007, 102:1979-1986.

49. Pletcher MJ, Hulley BJ, Houston T, Kiefe Cl, Benowitz N, Sidney S: Menthol cigarettes, smoking cessation, atherosclerosis, and pulmonary function: the Coronary Artery Risk Development in Young Adults (CARDIA) Study. Arch Intern Med 2006, 166:1915-1922.

50. Gandhi KK, Foulds J, Steinberg MB, Lu SE, Williams JM: Lower quit rates among African American and Latino menthol cigarette smokers at a tobacco treatment clinic. Int J Clin Pract 2009, 63:360-367.

51. Sidney S, Tekawa IS, Friedman GD, Sadler MC, Tashkin DP: Mentholated cigarette use and lung cancer. Arch Intern Med 1995, 155:727-732.

52. Muscat JE, Richie JP, Stellman SD: Mentholated cigarettes and smoking habits in whites and blacks. Tob Control 2002, 11:368-371.

53. Brooks DR, Palmer JR, Strom BL, Rosenberg L: Menthol cigarettes and risk of lung cancer. Am J Epidemiol 2003, 158:609-616.

54. Fu SS, Okuyemi KS, Partin MR, Ahluwalia JS, Nelson DB, Clothier BA, Joseph AM: Menthol cigarettes and smoking cessation during an aided quit attempt. Nicotine Tob Res 2008, 10:457-462.

55. Businelle MS, Kendzor DE, Costello TJ, Cofta-Woerpel L, Li Y, Mazas CA Vidrine Jl, Reitzel LR, Cinciripini PM, Ahluwalia JS, et al: Light versus heavy smoking among African American men and women. Addict Behav 2009, 34:197-203.

56. Murray RP, Connett JE, Skeans MA, Tashkin DP: Menthol cigarettes and health risks in Lung Health Study data. Nicotine Tob Res 2007, 9:101-107.

57. Collins CC, Moolchan ET: Shorter time to first cigarette of the day in menthol adolescent cigarette smokers. Addict Behav 2006, 31:1460-1464.

58. Harris KJ, Okuyemi KS, Catley D, Mayo MS, Ge B, Ahluwalia JS: Predictors of smoking cessation among African-Americans enrolled in a randomized controlled trial of bupropion. Prev Med 2004, 38:498-502.

59. Li Q, Hyland A, Giovino G, Bauer J, Cummings M: Mentholated cigarettes and indicators of nicotine dependence. National conference on tobacco or health National conference on tobacco or health, Chicago, Illinois; 2005, May 4-6 2005.

60. Bover MT, Foulds J, Steinberg MB, Richardson D, Marcella SW: Waking at night to smoke as a marker for tobacco dependence: patient characteristics and relationship to treatment outcome. International Journal of Clinical Practice 2008, 62:182-190. 
61. Cropsey KL, Weaver MF, Eldridge GD, Villalobos GC, Best AM, Stitzer ML: Differential success rates in racial groups: results of a clinical trial of smoking cessation among female prisoners. Nicotine Tob Res 2009, 11:690-697.

62. Okuyemi KS, Ahluwalia JS, Ebersole-Robinson M, Catley D, Mayo MS, Resnicow D: Does menthol attenuate the effect of bupropion among African American smokers? Addiction 2003, 98:1387-1393.

63. Foulds J, Gandhi KK, Steinberg MB, Richardson DL, Williams JM, Burke MV, Rhodes GG: Factors associated with quitting smoking at a tobacco dependence treatment clinic. Am J Health Behav 2006, 30:400-412.

64. Gundersen DA, Delnevo CD, Wackowski O: Exploring the relationship between race/ethnicity, menthol smoking, and cessation, in a nationally representative sample of adults. Prev Med 2009, 49:553-557.

65. US Surgeon General: Reducing the health consequences of smoking. 25 years of progress. A report of the Surgeon General Rockville, Maryland: US Department of Health and Human Services; Public Health Services; 1989, 89-8411 [http://www.surgeongeneral.gov/library/reports/index.html], DHHS Publication No. (CDC).

66. Jemal A, Siegel R, Ward E, Hao Y, Xu J, Thun MJ: Cancer statistics, 2009. CA Cancer J Clin 2009, 59:225-249.

67. Sidney S, Tekewa I, Friedman GD: Mentholated cigarette use among multiphasic examinees, 1979-86. Am J Public Health 1989, 79:1415-1416.

68. Kabat GC, Hebert JR: Use of mentholated cigarettes and lung cancer risk. Cancer Res 1991, 51:6510-6513.

69. Carpenter $\mathrm{CL}$, Jarvik ME, Morgenstern H, McCarthy WJ, London SJ: Mentholated cigarette smoking and lung-cancer risk. Ann Epidemiol 1999, 9:114-120.

70. Novotny TE, Warner KE, Kendrick JS, Remington PL: Smoking by Blacks and Whites: socioeconomic and demographic differences. Am J Public Health 1988, 78:1187-1189.

71. Sterling TD: Theory (or model) of the joint influence of occupational exposure to carcinogenic dust and to cigarette smoke and occupational lung cancer. Exp Pathol 1989, 37:181-185.

72. US Surgeon General: Tobacco use among US racial/ethnic minority groups African Americans, American Indians and Alaska Natives, Asian Americans and Pacific Islanders, and Hispanics. A report of the Surgeon General Atlanta, Georgia: US Department of Health and Human Services, Centers for Disease Control and Prevention, National Center for Chronic Disease Prevention and Health Promotion, Office on Smoking and Health; 1998 [http://www. surgeongeneral.gov/library/reports/index.html].

73. Wagenknecht LE, Cutter GR, Haley NJ, Sidney S, Manolio TA, Hughes GH, Jacobs DR: Racial differences in serum cotinine levels among smokers in the Coronary Artery Risk Development in (young) Adults study. Am J Public Health 1990, 80:1053-1056.

74. English PB, Eskenazi B, Christianson RE: Black-white differences in serum cotinine levels among pregnant women and subsequent effects on infant birthweight. Am J Public Health 1994, 84:1439-1443.

75. Eskenazi B, Bergmann Jj: Passive and active maternal smoking during pregnancy, as measured by serum cotinine, and postnatal smoke exposure. I. Effects on physical growth at age 5 years. Am J Epidemiol 1995, 142:S10-S18.

76. Caraballo RS, Giovino GA, Pechacek TF, Mowery PD, Richter PA, Strauss WJ, Sharp DJ, Eriksen MP, Pirkle JL, Maurer KR: Racial and ethnic differences in serum cotinine levels of cigarette smokers. Third National Health and Nutrition Examination Survey, 1988-1991. JAMA 1998, 280:135-139.

77. Pérez-Stable EJ, Herrera B, Jacob P III, Benowitz NL: Nicotine metabolism and intake in black and white smokers. JAMA 1998, 280:152-156.

78. Gardner MJ, Altman DG, editors: Statistics with confidence. Confidence intervals and statistical guidelines London: British Medical Journal; 1989.

79. Fleiss JL, Gross AJ: Meta-analysis in epidemiology, with special reference to studies of the association between exposure to environmental tobacco smoke and lung cancer: a critique. J Clin Epidemiol 1991, 44:127-139.

80. Hamling J, Lee $P$, Weitkunat $R$, Ambühl M: Facilitating meta-analyses by deriving relative effect and precision estimates for alternative comparisons from a set of estimates presented by exposure level or disease category. Stat Med 2008, 27:954-970.

81. Wells GA, Shea B, O'Connell D, Peterson J, Welch V, Losos M, Tugwell P: The Newcastle-Ottawa Scale (NOS) for assessing the quality of nonrandomised studies in meta-analyses Ottawa Health Research Institute; [http://www.ohri. ca/programs/clinical_epidemiology/oxford.asp?status=print].
82. Egger M, Davey Smith G, Schneider M, Minder C: Bias in meta-analysis detected by a simple, graphical test. BMJ 1997, 315:629-634.

83. Stellman SD, Chen Y, Muscat JE, Djordjevic MV, Richie JP Jr, Lazarus P, Thompson S, Altorki N, Berwick M, Citron ML, et al: Lung cancer risk in white and black Americans. Ann Epidemiol 2003, 13:294-302.

84. Jöckel $\mathrm{KH}$, Pohlabeln $\mathrm{H}$, Jahn I: Use of menthol cigarettes and risk of lung cancer. Biom J 2004, 46(S1):33.

85. Etzel CJ, Kachroo S, Liu M, D’Amelio A, Dong Q, Cote ML, Wenzlaff AS, Hong WK, Greisinger AJ, Schwartz AG, et al: Development and validation of a lung cancer risk prediction model for African-Americans. Cancer Prev Res 2008, 1:255-265.

86. Lee PN: Comparison of autopsy, clinical and death certificate diagnosis with particular reference to lung cancer. A review of the published data. In APMIS. Volume 102. Copenhagen: Munksgaard; 1994:(Suppl 45):1-42.

87. Feinstein AR, Wells CK: Cigarette smoking and lung cancer: the problems of "detection bias" in epidemiologic rates of disease. Trans Assoc Am Physicians 1974, 87:180-185.

88. Wells CK, Feinstein AR: Detection bias in diagnostic pursuit of lung cancer. Am J Epidemiol 1988, 128:1016-1026.

89. Peach H, Ellard GA, Jenner PJ, Morris RW: A simple, inexpensive urine test of smoking. Thorax 1985, 40:351-357.

\section{Pre-publication history}

The pre-publication history for this paper can be accessed here: http://www.biomedcentral.com/1471-2466/11/18/prepub

doi:10.1186/1471-2466-11-18

Cite this article as: Lee: Systematic review of the epidemiological evidence comparing lung cancer risk in smokers of mentholated and unmentholated cigarettes. BMC Pulmonary Medicine 2011 11:18.

\section{Submit your next manuscript to BioMed Central and take full advantage of:}

- Convenient online submission

- Thorough peer review

- No space constraints or color figure charges

- Immediate publication on acceptance

- Inclusion in PubMed, CAS, Scopus and Google Scholar

- Research which is freely available for redistribution 